Distribution and Diversity of

Fungal Species in and Adjacent to the

Los Alamos National Laboratory

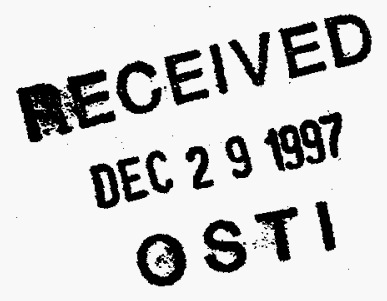

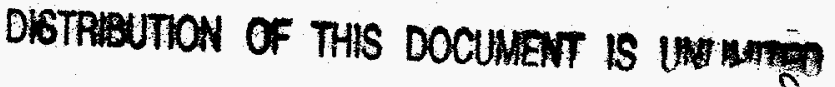 MASTER
}

\section{Los Alamos for the United States Department of Energy under contract W-7405-ENG-36. 
An Affirmative Action/Equal Opportunity Employer

\section{This report was prepared as an account of zoork sponsored by an agency of the United States} Government. Neither The Regents of the Unioersity of California, the United States

Government nor any agency thereof, nor any of their employees, makes any warranty, express or implied, or assumes any legal liability or responsibility for the accuracy, completeness, or usefulness of any information, apparatus, product, or process disclosed, or represents that its use would not infringe privately owned rights. Reference herein to any specific commercial product, process, or service by trade name, trademark, manufacturer, or otherwise, does not necessarily constitute or imply its endorsement, recommendation, or favoring by The Regents of the University of California, the United States Government, or any agency thereof. The views and opinions of authors expressed herein do not necessarily state or reflect those of The Regents of the University of California, the United States Government, or any agency thereof. Los Alamos National Laboratory strongly supports academic freedom and a researcher's right to publisiz; as an institution, however, the Laboratory does not endorse the viewpoint of a publication or guarantee its technical correctness. 


\section{DISCLAIMER}

Portions of this document may be illegible electronic image products. Images are produced from the best available original document. 


\section{Distribution and Diversity of}

Fungal Species in and Adjacent to the

Los Alamos National Laboratory

Randy G. Balice

Nelson Jarmie*

Fran J. Rogers*

*Consultant at Los Alamos National Laboratory, Mycology Associates, 116 Sierra Vista Drive, Los Alamos, NM 87544

\section{Los Alamos \\ NATIONAL LABORATORY \\ Los Alamos, New Mexico 87545}




\title{
Distributions and Diversity of Fungal Species in and Adjacent to the Los Alamos National Laboratory
}

by

\author{
Randy G. Balice, Nelson Jarmie, and Fran J. Rogers
}

\begin{abstract}
Previously archived information representing 43 sample locations was used to perform a preliminary evaluation of the distributions and diversity of fungal species at the Los Alamos National Laboratory and in adjacent environments. Presence-absence data for 71 species of fungi in five habitats, piñon-juniper, canyon-bottom ponderosa pine, ponderosa pine, canyon-bottom mixed conifer, and mixed conifer were analyzed. The results indicate that even though fungi occur in each of the habitats, fungal species are not distributed evenly among these habitats. The richness of fungal species is greater in the canyon-bottom mixed conifer and mixed conifer habitats than in the piñon-juniper, canyonbottom ponderosa pine or ponderosa pine habitats. All but three of the fungal species were recorded in either the canyon-bottom mixed conifer or the mixed conifer habitats, and all but seven of the fungal species were found in the mixed conifer habitat. In addition, species fidelity increases from the piñon-juniper to the mixed conifer. Five of the species have a high fidelity to the mixed conifer, and 13 species have a high fidelity to the either the canyon-bottom mixed conifer or the mixed conifer habitats. In contrast, only eight fungal species were found in the piñon-juniper habitat, and none of these were found with high fidelity or in high abundance. Finally, only two species of fungi were collected in all five of the habitats.
\end{abstract}

\section{Introduction}

Diversity is a measure of the number of species and their relative abundance in communities (Lincoln et al. 1982). Although diversity is easy to comprehend and conceptualize, it is difficult to quantify and analyze in a meaningful way (Harper 1977, Magurran 1988, McIntosh 1985). Despite this elusiveness, diversity has remained one of the central themes of ecology. This is evident from the following definition offered by Krebs (1994); "Ecology is the scientific study of the interactions that determine the distribution and abundance of organisms." According to the definition, the elements of diversity are integral components of all subdisciplines that constitute the science of ecology. 
Southwood (1987) contends that the most fundamental description of the nature of a biological community is provided by a measure of its diversity. Ecological communities do not all contain the same numbers of species, and one of the basic questions of ecology is why do some communities support more species than other communities (Whittaker 1975, Krebs 1994). Although these relationships may appear to be of academic interest only, diversity is also important to the applied sciences. For instance, in addition to being useful for describing the natural world, diversity is also important for evaluating the wellbeing of ecosystems (Magurran 1988). In particular, diversity is an important component to investigations and developments in biogeochemistry and nutrient cycling, keystone species and functional groups of species, vegetational succession and habitat modification, and policy decisions (Schulze and Mooney 1994).

Fungi are important components of ecosystems (Harper 1977, Pegg and Ayres 1987, Isaac 1992, Murphy 1996). They cooperate in mycorrhizae (Allan 1991), act as disease organisms that can alter community structure (Burdon 1982, 1987, Agrios 1988, Balice 1990), and recycle nutrients through decomposition (Barbour et al. 1987). Because of their importance to ecosystem functions and to the health of ecosystems, it is desirable to learn more about the distributions and diversity of fungi.

The results of a recent survey of macroscopic fungi at the Los Alamos National Laboratory (LANL) and in its surrounding environments provided an opportunity to evaluate the regional distributions and diversity of fungal species. Between 1991 and 1995, Jarmie and Rogers $(1996,1997)$ surveyed and collected macroscopic fungi (Kingdom, Eumycota) at 43 sample locations in Los Alamos County (LAC), the Bandelier National Monument (BNM), and LANL. These fungal samples were identified to the genus, species or subspecies level, and this information along with all associated environmental descriptors was entered into a database. The resulting database consists of 1,048 fungal collections, representing 140 genera and 227 species.

The current study employed the database to investigate fungal distributions and diversities. A subset of the data was defined, and a preliminary analysis was performed on presence-absence data for this collection of fungal species. The objectives of the analysis were to explore (1) the distributions of fungal species across selected habitat zones and (2) the diversity of fungi within and between these habitats.

\section{Environmental Setting}

LANL covers $112 \mathrm{sq} \mathrm{km}$ (43 sq mi) of land. It is located on the eastern slopes of the Jemez Mountains, approximately $120 \mathrm{~km}(80 \mathrm{mi})$ north of Albuquerque and $40 \mathrm{~km}$ (25 mi) northwest of Santa Fe (Figure 1). LANL is largely, but not completely, contained in Los Alamos County, the northeastern portion of LANL being in Santa Fe County. Los Alamos County land is administered by County governmental agencies, LANL, the Santa Fe National Forest of the U.S. Forest Service, and Bandelier National Monument. Bandelier National Monument extends to the south and the Santa Fe National Forest continues to the north and to the southeast. LANL and Los Alamos County are also bordered on the east by the Pueblo of San Ildefonso. Two populated 


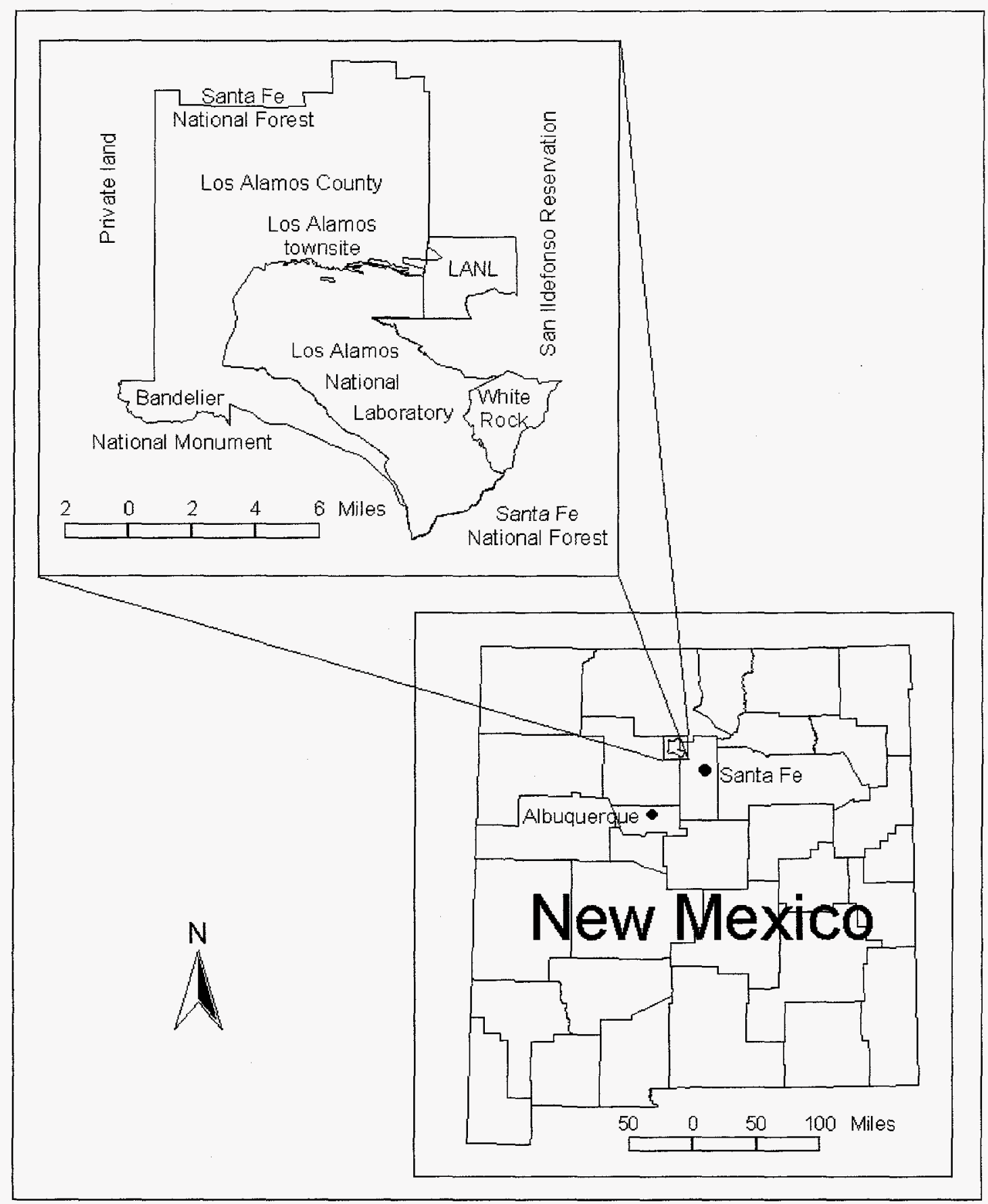

Figure 1. Location of Los Alamos County and Los Alamos National Laboratory. 
areas, Los Alamos townsite and White Rock townsite are located adjacent to LANL on the north and southeast, respectively.

LANL, Los Alamos County, and their neighboring administrative entities occupy lands that span an elevational gradient that ranges from approximately $1,631 \mathrm{~m}(5,350 \mathrm{ft})$, adjacent to the Rio Grande, to 3,199 $\mathrm{m}(10,496 \mathrm{ft})$ at its western extremities (Figure 2). White Rock Canyon, a rugged gorge that contains the Rio Grande occupies the lowest elevations. The Sierra de los Valles, a segment of the Jemez Mountains, is found to the west of LANL and in the western portions of Los Alamos County. Most of the LANL facilities and urban areas are located in the middle elevations, between $1,981 \mathrm{~m}$ and $2,286 \mathrm{~m}(6,500 \mathrm{ft}$ and $7,500 \mathrm{ft})$.

The elevational gradient in the LANL region encompasses five major vegetational cover types that reflect changes in climatic conditions from low elevations to high elevations (Figure 3). These major cover types are defined by their dominant tree species and structural characteristics as follows: juniper savannas, piñon-juniper woodlands, ponderosa pine forests, mixed conifer forests and spruce-fir forests (Balice et al. 1997). The relationships between the vegetational zones and elevational and topographic conditions are shown in Figure 4. The additional cover types displayed in Figure 3 will not be discussed in detail in this report since they are related to topographic, geologic or edaphic conditions, past disturbances, or human developments. The juniper savannas were not included in the macroscopic fungi survey by Jarmie and Rogers $(1996,1997)$ and will also not be considered further in this report. The remaining four major vegetational cover types are briefly described in the following paragraphs.

Piñon-juniper woodlands Although piñon-juniper woodlands can extend to as low as $1,676 \mathrm{~m}(5,500 \mathrm{ft})$ on protected topographic positions, they are the dominant, upland community type between $1,768 \mathrm{~m}$ and $2,134 \mathrm{~m}(5,800 \mathrm{ft}$ and $7,000 \mathrm{ft}$ ) in elevation (Foxx and Tierney 1980, Balice et al. 1997). They also can be found as high as $2,195 \mathrm{~m}$ $(7,200 \mathrm{ft})$ on southerly facing exposures.

Piñon-juniper woodlands range from open-canopied to closed-canopied communities (Foxx and Tierney 1984; Balice et al. 1997). The dominant tree species are one-seed juniper (Juniperus monosperma) or piñon (Pinus edulis). The relative dominance between these two species depends on the elevation. Within the range of these woodlands, one-seed juniper is more abundant at lower elevations, while piñon is more abundant at higher elevations. Other tree species are absent or rare.

Piñon-juniper woodlands are patchy communities where the understories are dominated by an assortment of grasses and shrubs. Typical graminoid dominants include mountain muhly (Muhlenbergia montana) and blue grama (Bouteloua gracilis). In the shrub layer, oaks (Quercus gambelii and $Q$. undulata) and mountain mahogany (Cercocarpus montanus) are common species.

Ponderosa pine forest Ponderosa pine forests extend to as low as $1,829 \mathrm{~m}(6,000 \mathrm{ft})$ in some of the protected canyons in the LANL region (Foxx and Tierney 1980, Balice et al. 


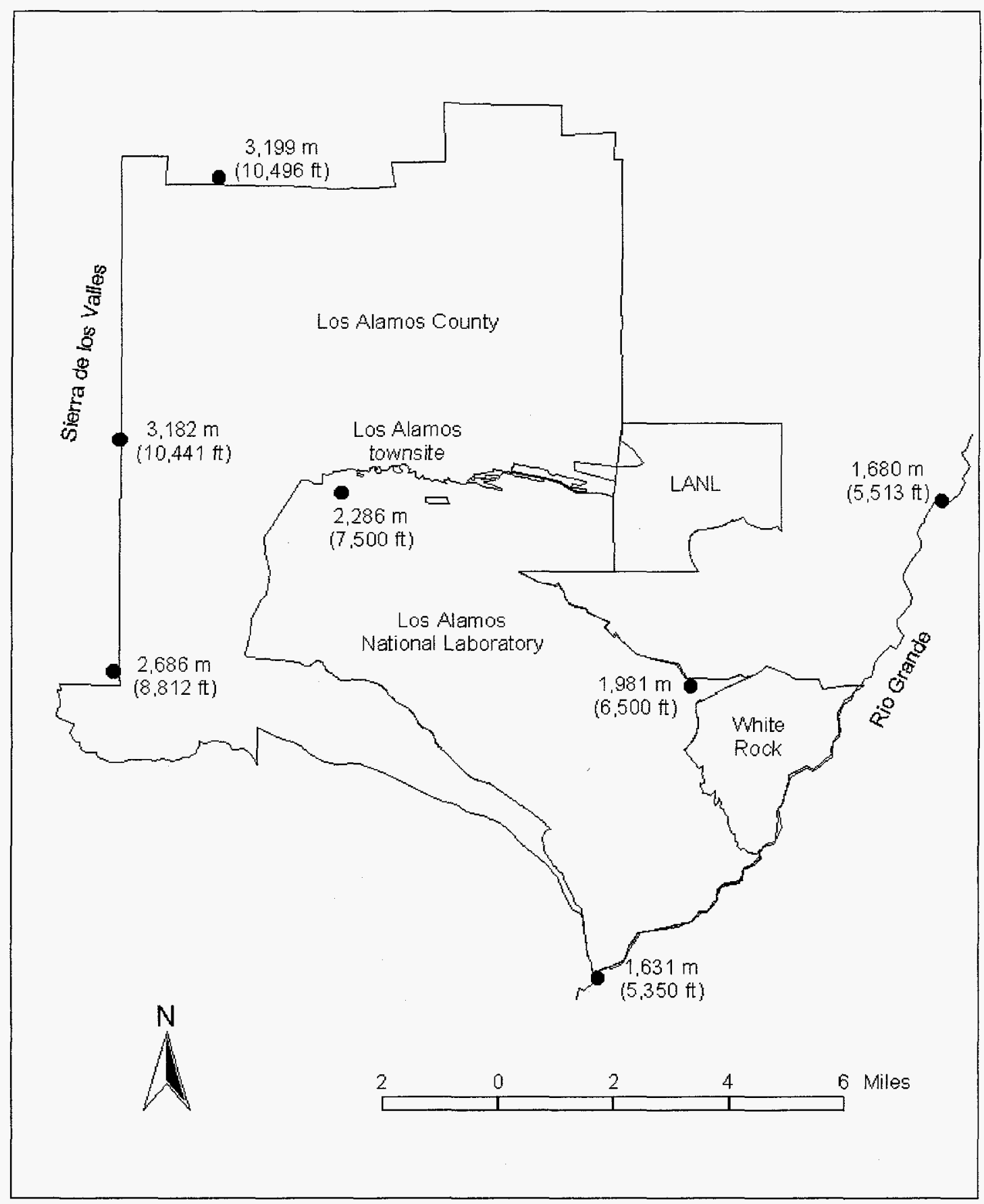

Figure 2. Los Alamos County and Los Alamos National Laboratory. 


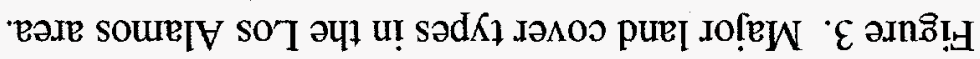

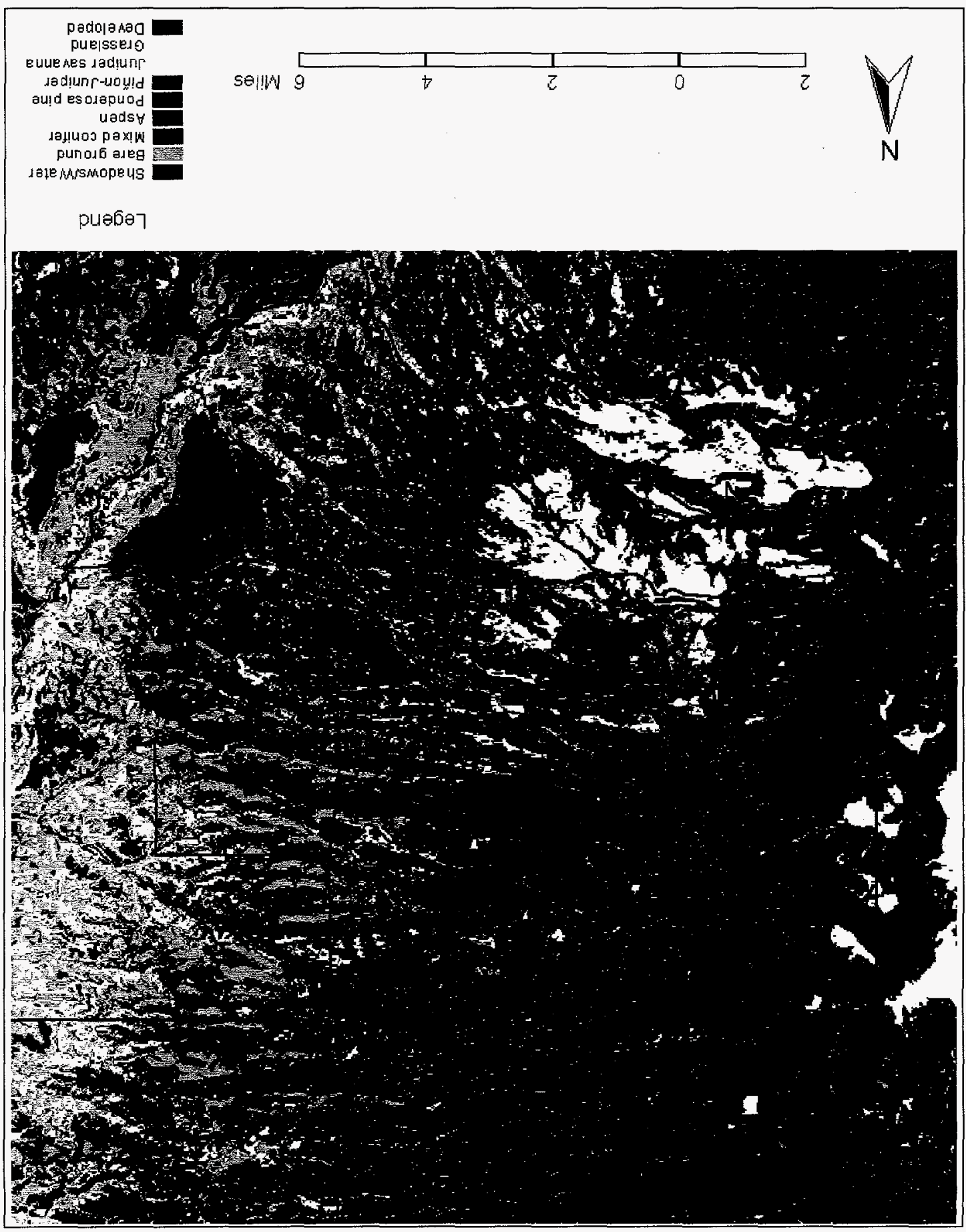





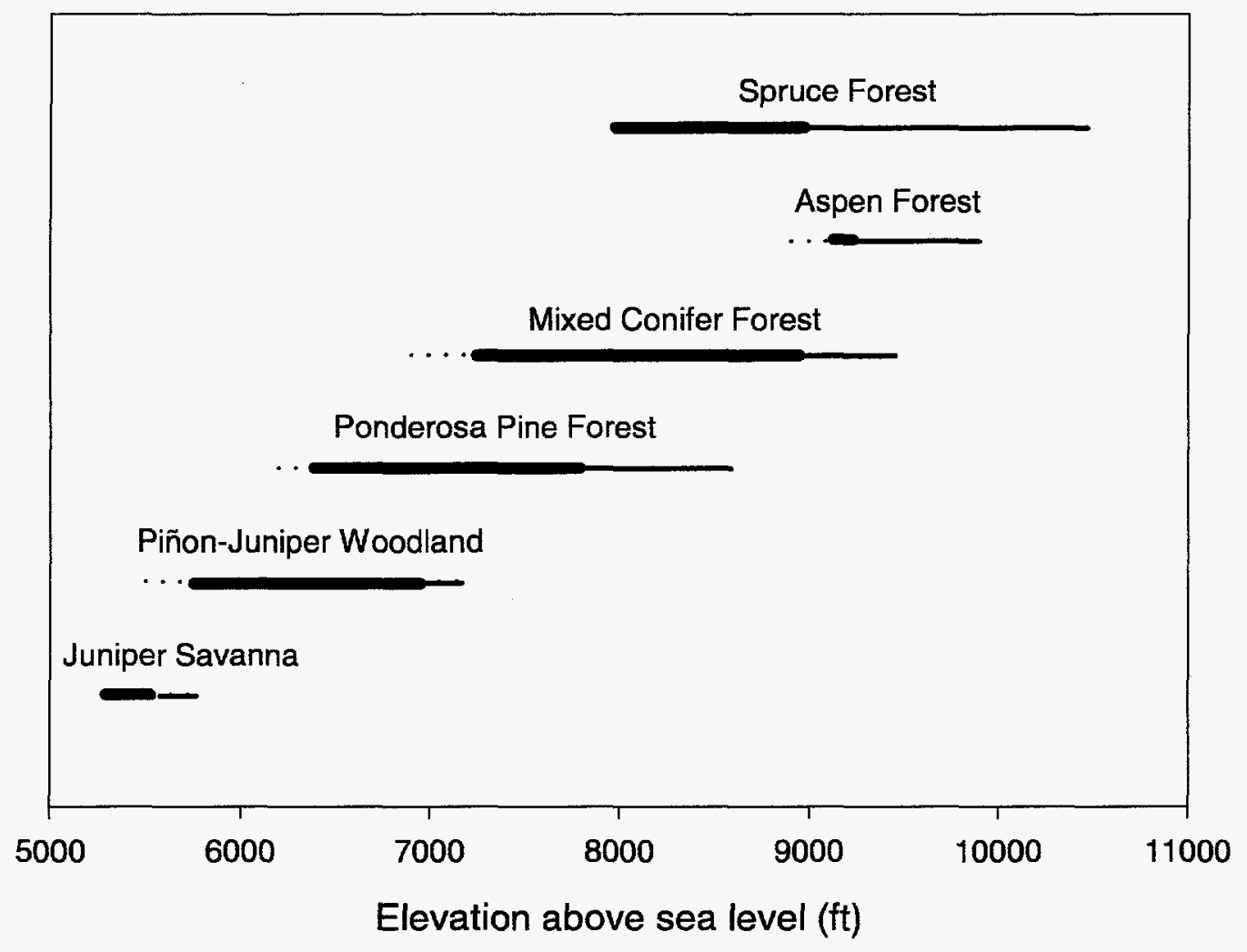

$\ldots \ldots$ North-facing exposures
Level terrain
South-facing exposures

Figure 4. Elevational ranges of selected forested cover types. 
1997). At these lower extremities ponderosa pine forests intergrade with piñon-juniper woodland. On the mesas and the lower slopes of the Sierra de los Valles, ponderosa pine forests extend to $2,377 \mathrm{~m}(7,800 \mathrm{ft})$ in elevation. They may also be found at higher elevations on steep, south-facing slopes.

This cover type is an open or closed forest. Ponderosa pine (Pinus ponderosa) is the dominant tree species. One-seed juniper and piñon may also be present, particularly at lower elevations, but other tree species are typically absent or rare. At higher elevations, Douglas fir (Pseudotsuga menziesii) and Rocky Mountain juniper (Juniperus scopulorum) can be found in ponderosa pine forests. Douglas fir may be especially common in areas that were protected from wildfires for prolonged periods.

The understories in the ponderosa pine zone are typically shrubby, with significant amounts of graminoid species also being present. Gambel oak (Quercus gambelii) and Colorado barberry (Berberis fendleri) are common associates in the shrub stratum. The most abundant graminoid species include sedges (Carex spp.), blue grama, mountain muhly, little bluestem (Scizachyrium scoparium), and pine dropseed (Blepharoneuron tricholepis).

Mixed conifer forests Mixed conifer forests begin as intergrades with ponderosa pine communities and as stringers on north aspects of the canyons above $2,103 \mathrm{~m}(6,900 \mathrm{ft})$ in elevation (Foxx and Tierney 1980, Balice et al. 1997). These communities continue to $2,743 \mathrm{~m}(9,000 \mathrm{ft})$ on eastern exposures and on flat topographic positions. On southern exposures, mixed conifer forests extend to $2,896 \mathrm{~m}(9,500 \mathrm{ft})$.

Douglas fir and white fir (Abies concolor) are the typical overstory dominants in mixed conifer forests. Ponderosa pine and aspen (Populus tremuloides) are also typically present. Frequently ponderosa pine is represented by a few, large individuals that are remnants from previous, open-canopied forest stands and by numerous pole-sized trees that have recently become established. Limber pine (Pinus flexilis) can also be found in mixed conifer forests, especially on rocky, ridgeline positions.

The understories in the mixed conifer forests are extremely variable. Shrubs, including ninebark (Physocarpus monogynous), kinnikinnik (Arctostaphylos uva-ursi), Gambel oak, wild rose (Rosa woodsii), cliffbush (Jamesia americana), Oregon grape (Berberis repens), myrtle boxleaf (Pachystima myrsinites), mountain maple (Acer glabrum), and dwarf juniper (Juniperus communis), are found along with numerous species of herbs and graminoids. Among the grasses and grass-like species, sedges, nodding brome (Bromus inermis), and muttongrass (Poa fendleriana) are the most commonly found.

Spruce-fir forests Spruce-fir forests can be found on north aspects as low as $2,438 \mathrm{~m}$ $(8,000 \mathrm{ft})$ and on more exposed slopes as low as $2,743 \mathrm{~m}(9,000 \mathrm{ft})$ in the Sierra de los Valles (Foxx and Tierney 1984; Balice et al. 1997). These communities extend to the highest elevations of the Sierras $(3,199 \mathrm{~m}[10,496 \mathrm{ft}])$. 
Engelmann spruce (Picea engelmannii) and Douglas fir are typically the dominant tree species, although white fir may also be abundant. Aspen (Populus tremuloides) is also a major overstory species in some areas. On north-facing slopes aspen is present as a successional species. However, on south-facing slopes with bouldery soils, aspen appears to be a persistent species and may dominate these sites indefinitely.

The understories in the spruce-fir forests are typically shrubby and herbaceous. Shrubs are represented by mountain maple, cliffbush, ninebark, myrtle boxleaf, and whortleberry (Vaccinium myrtillus). Among the herbaceous species, Arizona peavine (Lathyrus arizonicus), sidebells (Pyrola secunda), false Solomon's seal (Smilacina racemosa), forest fleabane (Erigeron eximius), rattlesnake plantain (Goodyera oblongifolia) and Fendler meadowrue (Thalictrum fendleri) are commonly found. Bracken fern (Pteridium aquilinum) replaces many of these species in the aspen forests. Nodding brome is the only graminoid species that is widely distributed in the spruce-fir zone. Grasses, such as nodding brome and slender wheatgrass (Agropyron trachycaulum) become abundant only where aspen dominates the overstory.

\section{Methods}

The data analyzed in this project were provided by Jarmie and Rogers $(1996,1997)$. They had surveyed macroscopic fungi (Kingdom, Eumycota) from 1991 to 1995 at specified sample locations within LANL and in the surrounding areas. The fungal samples were identified to the genus, species or subspecies level and recorded in a database. As a result of this effort, 1,048 fungal collections, including 140 genera and 227 species, were obtained.

The network of sample sites that was surveyed by Jarmie and Rogers $(1996,1997)$ consisted of 43 sample locations at LANL, Bandelier National Monument, and the Santa Fe National Forest. Although urban areas were included in the sample, the primary focus of the survey was on forested and wooded areas on LANL property and in the immediate surroundings. This largely consists of forested or wooded mesas, canyons, and mountain slopes between the elevations of $1,829 \mathrm{~m}(6,000 \mathrm{ft})$ and 3,048 $\mathrm{m}(10,000 \mathrm{ft})$.

The first step in the analysis was to define major habitat groupings that are consistent with previously defined vegetational cover types. This was accomplished by adopting five habitat classes previously defined by Jarmie and Rogers (1996). These habitat classes include piñon-juniper (P-J), canyon-bottom ponderosa pine (CBPP), ponderosa pine (PP), canyon-bottom mixed conifer (CBMC), and mixed conifer (MC). Each of the 43 original sampling locations was grouped into one of these habitats. These habitat groups correspond to selected Level I classes discussed in Balice et al. (1997) with the following exceptions. In the current report, both the ponderosa pine type and the mixed conifer type are subdivided into canyon and noncanyon environments. Also, since the mixed conifer forests and spruce-fir forests were not distinguished in the original database, all high elevation sampling locations were included in the mixed-conifer zone for this analysis. 
The second step in the analysis was to define the subset of the original database of 1,048 fungal collections that was suitable for analysis of fungal diversity. This required a reformatting of the database for a Windows operating system on the personal computer. Then, the data were reorganized by species, sample location, and by date of collection. Next, each fungal species with high identification reliability were retained for further analysis. To accomplish this, the following identification reliability codes were adopted from Jarmie and Rogers (1996):

1 "Well known, no doubt, species sure, no close brothers."

2 "Well identified, but slight possibility of being a near species in a close group."

3 "Genus sure, species likely but difficult to separate from closely related species."

4 "Genus only."

5 "Family only."

6 "Order only."

7 "Unknown."

Only collections with identification reliability codes of 1,2 , or 3 were included in this analysis. Grades 1 and 2 indicate a high level of confidence in the species identification, while grade 3 indicates a lower level of confidence in the species identification.

The resulting subset of fungi, 835 species, was sorted by habitat, by sample location, and by the date of the sample. Then, the mean number of fungal species collected per visit was calculated for each of the 43 sample locations. Means, standard deviations, and standard errors of the means were also calculated for each of the habitat groups. Next, a Kruskal-Wallis test (Conover 1980) was conducted to determine if the mean numbers of fungal species collected per visit per site were significantly different between the habitats.

The third step in the analysis was to identify the fungal species that were present in the study with sufficient frequency to merit distributional analyses, and to perform the analysis on a species-by-species basis. From the previously selected subset of 835 fungal species, all fungal species with two or more collections were retained for further analysis. The presence-absence data for each species with four or more occurrences were summed by sample location and grouped according to the five habitats. Constancy, the number of sample locations within a particular habitat where the species occurred, and percent constancy, the constancy value relative to the total number of sample locations in the habitat group, were calculated for each species. Finally, the species were grouped according to their respective fidelities to the five habitats. These fidelity groupings were tabulated and displayed graphically.

\section{$\underline{\text { Results }}$}

The subdivisions of the sample locations into habitat zones are provided as separate tables in Appendix A. The approximate location of each sample site is shown in Figure 5. Six, ten, seven, six, and fourteen sample locations were grouped into the P-J, CBPP, PP, CBMC, and MC habitats, respectively. In addition to summarizing the habitat zones, 


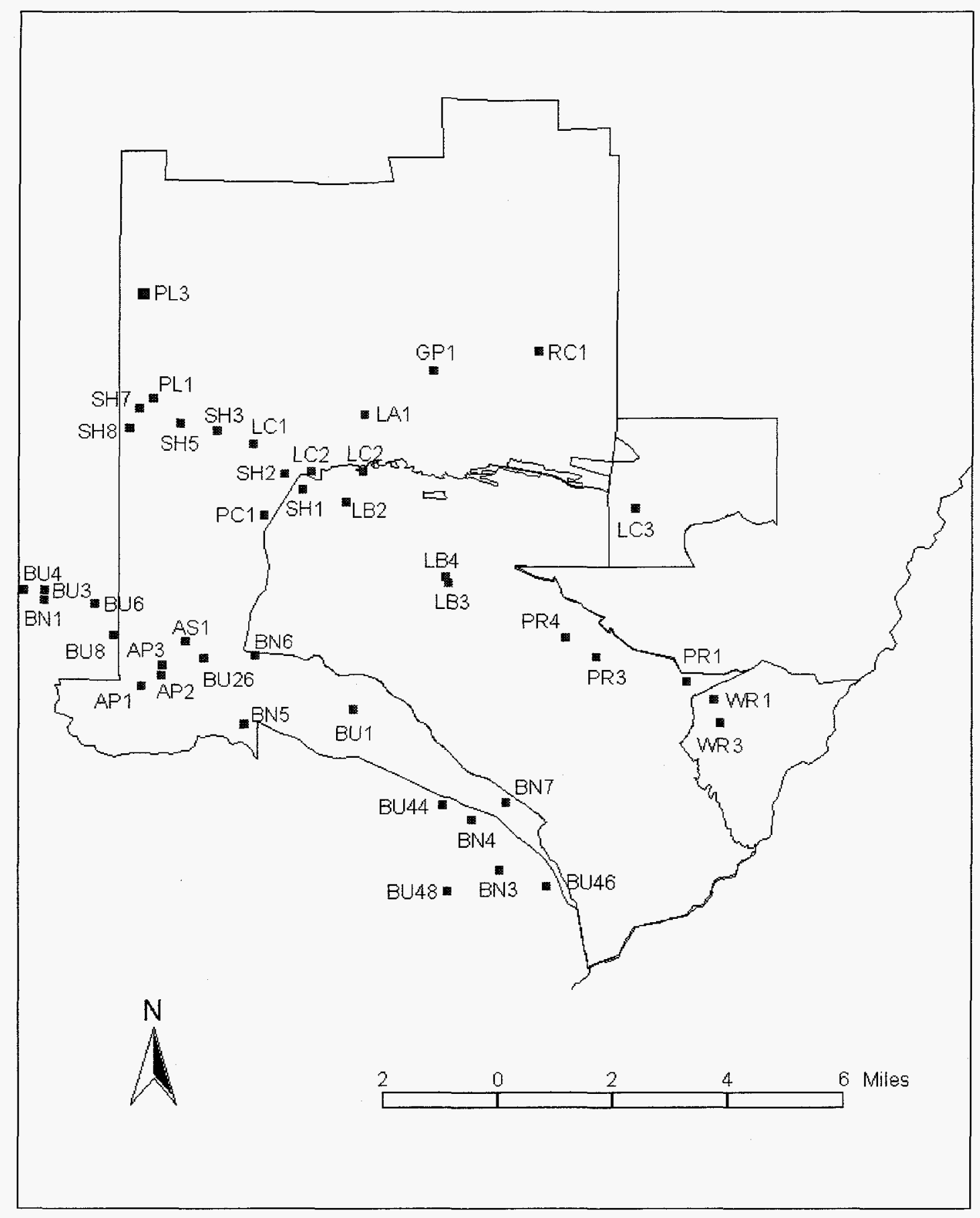

Figure 5. Fungi sample locations. 
Appendix A also includes the codes of the sample locations, the approximate elevations in feet, a brief description for the location of each sample site, the number of sample visits, and the total number of fungal samples collected at each site.

The tables in Appendix A also list summary statistics describing the numbers of fungi sampled at each site. The mean numbers of fungal species collected per visit per site and the standard errors of the means are displayed graphically in Figure 6. The calculated Kruskal-Wallis statistic ( $\mathrm{T}=16.78$ ) was significant at the 0.05 level when compared with the appropriate $t$ value $(t=1.69, \mathrm{df}=40)$. Pajred comparisons were significant for all of the habitat pairs except for the following combinations: P-J vs PP, CBPP vs PP and CBMC vs MC.

Figure 6 indicates a tendency for species diversity to increase from lower elevation habitats to higher elevation habitats. The CBMC and the $\mathrm{MC}$ habitats have the greatest species richness. The P-J habitat has the lowest species richness, although this value was not significantly different than the richness of PP. The species richness of CBPP and PP is intermediate between these two extremes.

Appendix B lists the fungal species with at least two collections that are considered to be somewhat reliable at the species level. A total of 130 species, representing 748 collections, is included in Appendix B. These species are arranged according to their prevalence in the database (number of samples) and according to their percent identification reliability (percent reliable). The percent identification reliability for each species is the number of collections with reliability codes of 1 or 2 relative to the number of collections with reliability codes 1,2 , or 3 . Appendix B also includes columns containing six-letter abbreviations for each fungal species and the associated taxonomic families.

Suillus granulatus and Crepidotus mollis are the most common species in the database with 22 and 20 collections, respectively (Appendix B). Overall, a total of 22 species is represented in the database by at least ten collections. A total of 71 fungal species, representing 609 collections, occurred in the database at least four times. These species were retained for further analysis. Most of these species were also identified with a high level of confidence.

The fungal constancies and percent constancies within each habitat are listed in Appendix C. Within this appendix, the fungal species are grouped according to their observed fidelities to specific habitat zones or to combinations of habitat zones. Those species that have a high fidelity to the mixed conifer zone are listed first. Species with increasing tendencies to occupy low-elevation environments follow in their respective groups. The species fall into a total of 11 fidelity groups. In addition to being tabulated in Appendix $\mathrm{C}$, the percent constancy results are also displayed graphically (see Appendix D-Figures 1 through 10).

All but three of the fungal species were found in either the CBMC or the MC habitats (Appendix C). Moreover, all but seven of the fungal species were collected in MC 


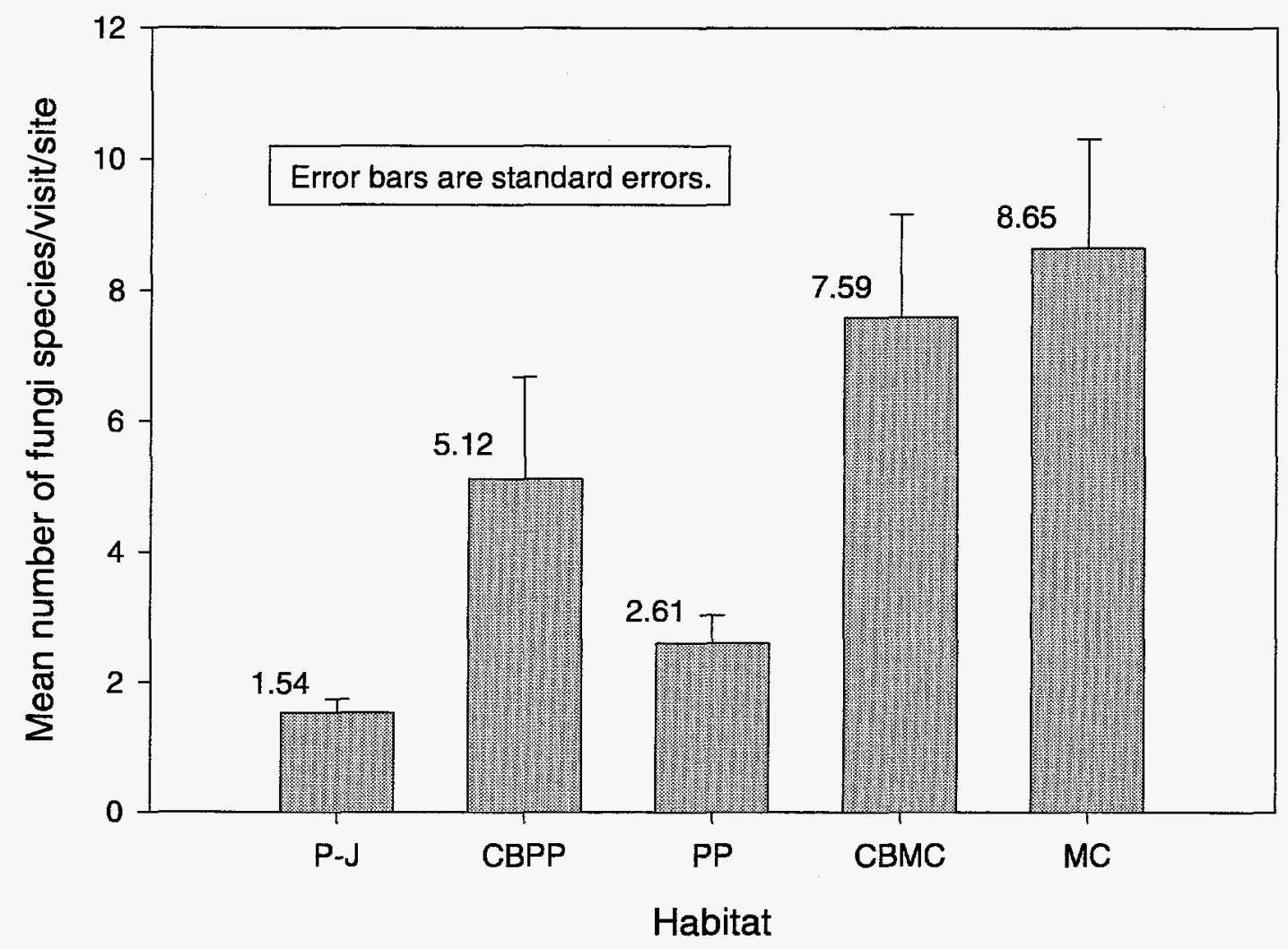

Figure 6. Mean number of fungal species by habitat. 
habitats. Five fungal species had high fidelity in the MC habitat and, 13 species had high fidelity in the CBMC and the MC habitats (Appendix D, Figures 1 and 2).

In contrast, only eight fungal species were collected in the P-J habitat (Appendix C). Of these, only Russula brevipes and Amanita constricta were collected more than once. None of the species had a high fidelity in the P-J zone, and only two species, Marasmius oreades and Agaricus campestris were collected with high fidelity in the CBPP and the PP habitats.

Most of the fungal species were collected in more that one habitat zone (Appendix C). Eleven species were collected primarily in higher elevation sites. Six species tended to occur in canyon-bottom positions, while eight fungal species tended to occur on mesa positions. Two fungal species, Lycoperdon perlatum and Russula brevipes, were collected in all five of the habitats.

\section{$\underline{\text { Discussion }}$}

Although fungal species were encountered in each of the habitats, they were not evenly distributed throughout the range of habitats. There was a clear tendency for the fungi to occur at higher elevations and in more moist habitats. This tendency appeared to be accentuated in 1997, which was wetter than normal. However, the reconnaissance surveys at the 43 sampling locations had been completed before 1997 . Therefore, this conclusion is based on qualitative observations.

The results of this analysis are considered to be preliminary because the measures of distributions and diversity are based on presence-absence data that were gathered during reconnaissance surveys. Future surveys of fungi would benefit from the development of a species abundance measure, a systematic sampling design that spans the growing season, and incorporation of extraneous factors, such as weather patterns, soils characteristics and disturbance history, into the analysis. These are not trivial issues and previous attempts by other investigators to incorporate these factors were frustrated by the reconnaissance sampling design, by the growth form of this Kingdom of organisms, and by the unpredictable and ephemeral fruiting habit of these species (Stolp 1988, Norvell 1996). Furthermore, fungi may be distributed in a patchy manner within seemingly homogeneous environments as a result of the uneven distribution of their hosts (Giller 1984).

Fungi have demonstrated their ability to diversify and specialize to take advantage of new environments (Murphy 1996). These species are essential to the normal functioning of ecosystems and the impacts of human activities may be harmful to fungi. There is a need to inventory fungi throughout the range of their environments. Only then can we determine the trends in the distributions and diversity of fungal species, begin to understand their importance to ecosystem health, and evaluate their interactions with humans. 


\section{$\underline{\text { References }}$}

Agrios, George N. 1988. Plant pathology, third edition. Academic Press, San Diego, California.

Allen, Michael F. 1991. The ecology of mycorrhizae. Cambridge University Press, Cambridge, England.

Balice, Randy G. 1990. Interactions between fungal root diseases and coniferous forest vegetation. Ph.D. dissertation, University of Idaho, Moscow, Idaho.

Balice, Randy G., Scott G. Ferran, Teralene S. Foxx. 1997. Preliminary Land Cover Classification for the Los Alamos Region. Los Alamos National Laboratory document LA-UR 97-4627 (November 1997).

Barbour, Michael G., Jack H. Burk, Wanna D. Pitts. 1987. Terrestrial plant ecology, second edition. Benjamin/Cummings Publishing, Menlo Park, California.

Burdon, Jeremy J. 1982. The effect of fungal pathogens on plant communities. Pages 99-112 in "The plant community as a working mechanism" (E.I. Newman, editor), Blackwell Scientific Publications, Oxford, England.

Burdon, Jeremy J. 1987. Diseases and plant population biology. Cambridge University Press, Cambridge, England.

Conover, W. J. 1980. Practical nonparametric statistics, second edition. John Wiley \& Sons, New York, New York.

Foxx, Teralene S. and Gail D. Tierney. 1980. Status of the flora of the Los Alamos National Environmental Research Park. LA-8050-NERP, Vol. I., Los Alamos Scientific Laboratory, Los Alamos, New Mexico (Figure 3. Overstory vegetation of Los Alamos environs.).

Foxx, Teralene S. and Gail D. Tierney. 1984. Status of the flora of the Los Alamos National Environmental Research Park, a historical perspective. LA-8050-NERP, Vol II, Los Alamos Scientific Laboratory, Los Alamos, New Mexico.

Giller, Paul S. 1984. Community structure and the niche. Chapman and Hall, London, England.

Harper, John L. 1977. Population biology of plants. Academic Press, London, England.

Isaac, Susan. 1992. Fungal-plant interactions. Chapman \& Hall, London, England. 
Jarmie, Nelson and Fran J. Rogers. 1996. A survey of Los Alamos County and Bandelier National Monument for Macroscopic Fungi. Los Alamos National Laboratory document LA-UR-96-3581.

Jarmie, Nelson and Fran J. Rogers. 1997. A survey of macromycete diversity in the Los Alamos National Laboratory and Bandelier National Monument; a preliminary report. Los Alamos National Laboratory report LA-13384-MS (November 1997).

Krebs, Charles J. 1994. Ecology: The experimental analysis of distribution and abundance, fourth edition. Harper Collins Publishers, New York, New York.

Lincoln, R.J., G.A. Boxshall and P.F. Clark. 1982. A dictionary of ecology, ecolution and systematics. Cambridge University Press, Cambridge, England.

Magurran, Anne E. 1988. Ecological diversity and its measurement. Princeton University Press, Princeton, New Jersey.

McIntosh, Robert P. 1985. The background of ecology; concept and theory. Cambridge University Press, Cambridge, England.

Murphy, John F. 1996. Fungal inventories-a status report and an exhortation. McIlvainea 12:75-88.

Norvell, Lorelei. 1996. Loving the chantrelle to death? The ten-year Oregon chantrelle project. McIlvainea 12:6-25.

Pegg, G.F. and Peter G. Ayres. 1987. Fungal infection of plants. Cambridge University Press, Cambridge, England.

Schulze, Ernst-Detlef and Harold A. Mooney (eds.). 1994. Biodiversity and ecosystem function. Springer-Verlag, Berlin, Germany.

Stolp, Heinz. 1988. Microbial ecology: organisms, habitat and activities. Cambridge University Press, Cambridge, England.

Southwood, T.R.E. 1987. The concept and nature of the community. Pp. 3-27 in Organization of Communities, Past and Present (Edited by J.H.R. Gee and P.S. Giller), Blackwell Scientific Publications, Oxford, England.

Whittaker, Robert H. 1975. Communities and ecosystems, second edition. Macmillan Publishing Company, New York, New York. 
Appendix A

Sampling Locations and Habitat Groups 
Table 1. Fungi sampling sites in the piñon-juniper habitat (P-J).

\begin{tabular}{cllcc}
\hline $\begin{array}{c}\text { Location } \\
\text { Code }^{\top}\end{array}$ & $\begin{array}{c}\text { Elevation } \\
\text { (feet) }\end{array}$ & Location description & $\begin{array}{c}\text { Number of } \\
\text { sample visits }\end{array}$ & $\begin{array}{c}\text { Total number of } \\
\text { fungi samples }\end{array}$ \\
\hline WR3 & 6480 & White Rock, 122 Piedra Loop, La Senda Subdivision & 6 & 18 \\
WR1 & 6500 & White Rock, 116 Sierra Vista, La Vista Subdivision & 6 & 7 \\
PR1 & 6540 & LANL, Pajarito Canyon at Cañada del Buey & 2 & 6 \\
PR3 & 6700 & LANL, Pajarito Canyon at Building 36-135, 1.8 mi northwest of Hwy 4 & 1 & 1 \\
BN7 & 6689 & Bandelier Nat. Mon., Juniper Campground & 2 & 5 \\
LB3 & 7300 & LANL, TA-67, mesa area & Totals & 19 \\
& & & & 5 \\
\hline
\end{tabular}

Mean number of fungi collections/visit/site

${ }^{1}$ Location codes are used for identifying the sample sites. 
Table 2. Fungi sampling sites in the canyon bottom ponderosa pine habitat (CBPP).

\begin{tabular}{|c|c|c|c|c|}
\hline $\begin{array}{l}\text { Location } \\
\text { Code }^{1}\end{array}$ & $\begin{array}{c}\text { Elevation } \\
\text { (feet) }\end{array}$ & Location description & $\begin{array}{l}\text { Number of } \\
\text { sample visits }\end{array}$ & $\begin{array}{l}\text { Total number of } \\
\text { fungi samples }\end{array}$ \\
\hline BU46 & 6000 & Bandelier Nat. Mon., Rainbow House & 1 & 15 \\
\hline BN3 & 6066 & Bandelier Nat. Mon., Frijoles Canyon, West of Headquarters & 14 & 50 \\
\hline BN4 & 6200 & Bandelier Nat. Mon., Frijoles Canyon, Ceremonial Cave area & 1 & 1 \\
\hline BU44 & 6300 & Bandelier Nat. Mon., Frijoles Canyon, 0.1 mi. west of Ceremonial Cave & 6 & 30 \\
\hline $\mathrm{RC} 1$ & 6500 & Los Alamos townsite, Rendija Canyon, 0.8 mi. east of Barranca Mesa & 2 & 4 \\
\hline PR4 & 6700 & LANL, Pajarito Canyon, at TA-18, 2.5 mi. northwest of Hwy 4 & 1 & 1 \\
\hline BU48 & 6580 & Bandelier Nat. Mon., trail between Lummis and Alamo Canyons & 2 & 23 \\
\hline GP1 & 7000 & Los Alamos townsite, Guaje Pines area & 3 & 14 \\
\hline BN5 & 7023 & Bandelier Nat. Mon., Frijoles Canyon, Upper Crossing & 2 & 6 \\
\hline \multirow[t]{2}{*}{ LB4 } & 7100 & LANL, Pajarito Canyon at TA-67 & 1 & 8 \\
\hline & & Totals & 33 & 152 \\
\hline
\end{tabular}

Mean number of fungi collections/visit/site

${ }^{1}$ Location codes are used for identifying the sample sites. 
Table 3. Fungi sampling sites in the ponderosa pine habitat (PP).

\begin{tabular}{cclcc}
\hline $\begin{array}{c}\text { Location } \\
\text { Code }^{1}\end{array}$ & $\begin{array}{c}\text { Elevation } \\
\text { (feet) }\end{array}$ & Location description & $\begin{array}{c}\text { Number of } \\
\text { sample visits }\end{array}$ & $\begin{array}{c}\text { Total number of } \\
\text { fungi samples }\end{array}$ \\
\hline BU1 & 7200 & Bandelier Nat. Mon., Burnt Mesa area & 5 & 11 \\
LB2 & 7400 & LANL, mesa area on southwest margin of TA-3 & 8 & 34 \\
LA1 & 7400 & Los Alamos townsite, Urban Park area & 6 & 28 \\
SH1 & 7500 & LANL, Ski Hill Road, at Santa Fe Nat. For., 0.2 mi. from Hwy 501 & 28 & 16 \\
BN6 & 7600 & Bandelier Nat. Mon., near Ponderosa Campground & 4 & 74 \\
SH2 & 8000 & Santa Fe Nat. For., Ski Hill Road, 0.8 mi. from Hwy 501 & 3 & 9 \\
AP2 & 8500 & Bandelier Nat. Mon., northeast of Apache Springs & 6 & 8 \\
& & & Totals & 65 \\
\hline
\end{tabular}

Mean number of fungi collections/visit/site

${ }^{1}$ Location codes are used for identifying the sample sites. 
Table 4. Fungi sampling sites in the canyon bottom mixed conifer habitat (CBMC).

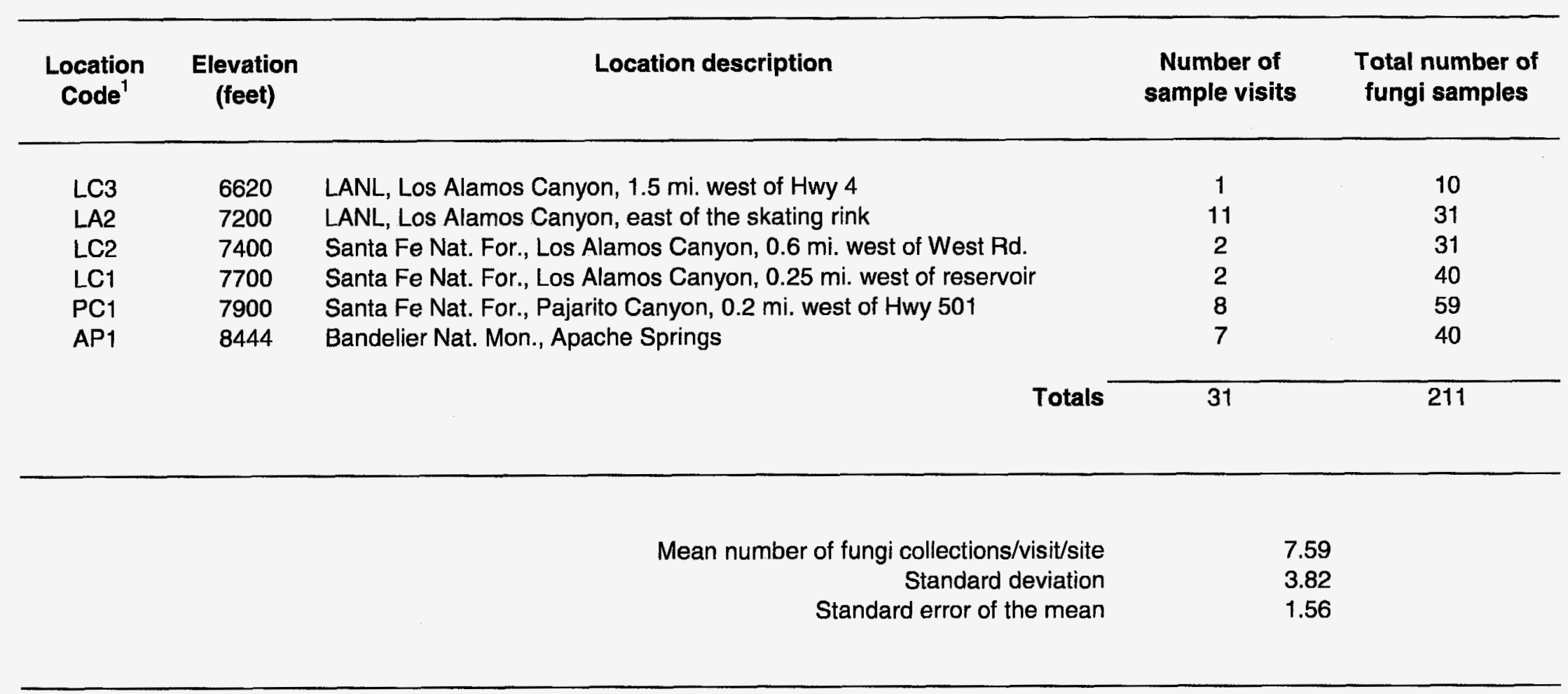

${ }^{1}$ Location codes are used for identifying the sample sites. 
Table 5. Fungi sampling locations in the mixed conifer habitat (MC).

\begin{tabular}{|c|c|c|c|c|}
\hline $\begin{array}{l}\text { Location } \\
\text { Code }^{1}\end{array}$ & $\begin{array}{c}\text { Elevation } \\
\text { (feet) }\end{array}$ & Location description & $\begin{array}{l}\text { Number of } \\
\text { sample visits }\end{array}$ & $\begin{array}{l}\text { Total number o } \\
\text { fungi samples }\end{array}$ \\
\hline BU26 & 8100 & Bandelier Nat. Mon., south of Hwy 4, 1.2 mi. west of Hwy 501 & 1 & 20 \\
\hline AS1 & 8200 & Santa Fe Nat. For., American Springs Rd., 0.3 mi. north of Hwy 4 & 1 & 13 \\
\hline AP3 & 8500 & Bandelier Nat. Mon., northeast of Apache Springs & 7 & 12 \\
\hline $\mathrm{SH} 3$ & 8600 & Santa Fe Nat. For., Ski Hill Road, turnout 2.6 mi. from Hwy 501 & 5 & 9 \\
\hline BN1 & 8949 & Bandelier Nat. Mon., 0.1 mi. southeast of Hwy 4-Rd 289 & 1 & 31 \\
\hline BU3 & 8960 & Bandelier Nat. Mon., 0.2 mi. northeast of Hwy 4-Rd 289 & 8 & 80 \\
\hline BU4 & 8960 & Bandelier Nat. Mon., 0.3 mi. northwest of Hwy 4-Rd 289 & 2 & 39 \\
\hline BU6 & 9000 & Bandelier Nat. Mon., Frijoles Canyon, 1.4 mi. north of park boundary & 2 & 18 \\
\hline BU8 & 9000 & Bandelier Nat. Mon., Frijoles Canyon, $0.8 \mathrm{mi}$. north of park boundary & 2 & 22 \\
\hline SH5 & 9200 & Santa Fe Nat. For., Ski Hill Road, $0.5 \mathrm{mi}$. below the ski lodge & 22 & 116 \\
\hline PL1 & 9200 & Santa Fe Nat. For., Upper Quemazon Trail, 0.2 mi. north of Ski Hill Rd & 5 & 32 \\
\hline $\mathrm{SH7}$ & 9260 & Pajarito Ski Area, $0.1 \mathrm{mi}$. southwest of Upper Quemazon Trailhead & 4 & 11 \\
\hline PL3 & 9540 & Santa Fe Nat. For., Pipeline Road at Guaje Canyon Trail & 2 & 14 \\
\hline \multirow[t]{2}{*}{$\mathrm{SH} 8$} & 10,000 & Pajarito Ski Area, $0.45 \mathrm{mi}$. southwest of Upper Quemazon Trailhead & 5 & 41 \\
\hline & & Totals & 67 & 458 \\
\hline
\end{tabular}

Mean number of fungi collections/visit/site

${ }^{1}$ Location codes are used for identifying the sample sites. 
Appendix B

Fungi Identified to Species and Collected at Least Twice 


\begin{tabular}{|c|c|c|c|c|c|}
\hline Abbreviation & Genus & Species & Family & Number of & Percent \\
\hline & & & & samples & reliable \\
\hline SUIGRA & Suillus & granulatus & Boletaceae & 22 & 82 \\
\hline CREMOL & Crepidotus & mollis & Crepidotaceae & 20 & 95 \\
\hline ZERCAM & Xeromphalina & campanella & Tricholomataceae & 18 & 100 \\
\hline RUSBRE & Russula & brevipes & Russulaceae & 17 & 100 \\
\hline FLAVEL & Flammulina & velutipes & Tricholomataceae & 16 & 100 \\
\hline BOLBAR & Boletus & barrowsii & Boletaceae & 15 & 100 \\
\hline SUILAK & Suillus & lakei & Boletaceae & 15 & 100 \\
\hline LACDEL & Lactarius & deliciosus & Russulaceae & 15 & 73 \\
\hline GOMGLU & Gomphidius & glutinosus & Gomphidiaceae & 14 & 100 \\
\hline POLARC & Polyporus & arcularius & Polyporaceae & 14 & 100 \\
\hline PLUCER & Pluteus & cervinus & Pluteaceae & 14 & 86 \\
\hline FOMPIN & Fomitopsis & pinicola & Polyporaceae & 13 & 100 \\
\hline LYCEPI & Lycogala & epidendrum & Reticulariaceae & 13 & 100 \\
\hline ARMMEL & Armillaria & mellea & Tricholomataceae & 12 & 8 \\
\hline HYGCON & Hygrophorus & conicus & Hygrophoraceae & 11 & 100 \\
\hline HYPLAC & Hypomyces & lactifluorum & Hypocreaceae & 11 & 100 \\
\hline GOMFLO & Gomphus & floccosus & Cantharellaceae & 11 & 91 \\
\hline LYCPER & Lycoperdon & perlatum & Lycoperdaceae & 11 & 91 \\
\hline PLEOST & Pleurotus & ostreatus & Tricholomataceae & 11 & 82 \\
\hline CYPCHR & Cyptotrama & chrysopeplum & Tricholomataceae & 10 & 100 \\
\hline PHOSQU & Pholiota & squarrosa & Strophariaceae & 10 & 30 \\
\hline AMAVAG & Amanita & vaginata & Amanitaceae & 10 & 10 \\
\hline AMAMUS & Amanita & muscaria v. mus. & Amanitaceae & 9 & 100 \\
\hline BJEADU & Bjerkandera & adusta & Polyporaceae & 9 & 100 \\
\hline DACPAL & Dacrymyces & palmatus & Dacrymycetaceae & 9 & 100 \\
\hline GANAPP & Ganoderma & applanatum & Polyporaceae & 9 & 100 \\
\hline TRIAB| & Trichaptum & abietinus & Polyporaceae & 9 & 100 \\
\hline LEUAMA & Leucopaxillus & amarus & Tricholomataceae & 9 & 78 \\
\hline AMAPAN & Amanita & pantherina & Amanitaceae & 9 & 33 \\
\hline CLAPYX & Clavicorona & pyxidata & Clavariaceae & 8 & 100 \\
\hline LACRUB & Lactarius & rubrilacteus & Russulaceae & 8 & 100 \\
\hline PHODES & Pholiota & destruens & Strophariaceae & 8 & 100 \\
\hline COPMIC & Coprinus & micaceus & Coprinaceae & 8 & 88 \\
\hline BOLCHR & Boletus & chrysenteron & Boletaceae & 8 & 0 \\
\hline RUSEME & Russula & emetica & Russulaceae & 8 & 0 \\
\hline HYGPUD & Hygrophorus & pudorinus & Hygrophoraceae & 7 & 100 \\
\hline HYGSPE & Hygrophorus & speciosus & Hygrophoraceae & 7 & 100 \\
\hline PHASCH & Phaeolus & schweinitzii & Polyporaceae & 7 & 100 \\
\hline PHYNID & Phyllotopsis & nidulans & Tricholomataceae & 7 & 100 \\
\hline PYCCIN & Pycnoporus & cinnabarinus & Polyporaceae & 7 & 100 \\
\hline GLOSEP & Gloepphyllum & sepiarium & Polyporaceae & 7 & 86 \\
\hline HYGCHR & Hygrophorus & chrysodon & Hygrophoraceae & 7 & 86 \\
\hline HEBSIN & Hebeloma & sinapizans & Cortinariaceae & 7 & 0 \\
\hline RUSMAC & Russula & maculata & Russulaceae & 7 & 0 \\
\hline AMACAE & Amanita & caesarea & Amanitaceae & 6 & 100 \\
\hline AURAUR & Auricularia & auricula & Auriculariaceae & 6 & 100 \\
\hline CLATRU & Clavariadelphus & truncatus & Clavariaceae & 6 & 100 \\
\hline CORCAL & Cortinarius & calochrous & Cortinariaceae & 6 & 100 \\
\hline HEBCRU & Hebeloma & crustiliniforme & Cortinariaceae & 6 & 100 \\
\hline
\end{tabular}


Ordered list of fungi,

2 or more occurrences

\begin{tabular}{|c|c|c|c|c|c|}
\hline Abbreviation & Genus & Species & Family & $\begin{array}{c}\text { Number of } \\
\text { samples }\end{array}$ & $\begin{array}{l}\text { Percent } \\
\text { reliable }\end{array}$ \\
\hline & & & & & \\
\hline AMACON & Amanita & constricta & Amanitaceae & 6 & 50 \\
\hline BOLEDU & Boletus & edulis & Boletaceae & 5 & 100 \\
\hline COPATR & Coprinus & atramentarius & Coprinaceae & 5 & 100 \\
\hline FULSEP & Fuligo & septica & Physacaceae & 5 & 100 \\
\hline HYGAUR & Hygrophoropsis & aurantiaca & Paxillaceae & 5 & 100 \\
\hline LECAUR & Leccinum & aurantiacum & Boletaceae & 5 & 100 \\
\hline LYCPYR & Lycoperdon & pyriforme & Lycoperdaceae & 5 & 100 \\
\hline GOMBON & Gomphus & bonari & Cantharellaceae & 5 & 80 \\
\hline POLVAR & Polyporus & varius & Polyporaceae & 5 & 80 \\
\hline PEZREP & Peziza & repanda & Pezizaceae & 5 & 60 \\
\hline GYRINF & Gyromitra & infula & Helvellaceae & 5 & 40 \\
\hline LACLAC & Laccaria & laccata & Tricholomataceae & 5 & 40 \\
\hline RUSROS & Russula & rosacea & Russulaceae & 5 & 0 \\
\hline AGACAM & Agaricus & campestris & Agaricaceae & 4 & 100 \\
\hline BISCIT & Bisporella & citrina & Leotiaceae & 4 & 100 \\
\hline CLIGIB & Clitocybe & gibba & Tricholomataceae & 4 & 100 \\
\hline COLPER & Coltricia & perennis & Polyporaceae & 4 & 100 \\
\hline HELCRI & Helvella & crispa & Helvellaceae & 4 & 100 \\
\hline MARORE & Marasmius & oreades & Tricholomataceae & 4 & 100 \\
\hline COPCOM & Coprinus & comatus & Coprinaceae & 4 & 75 \\
\hline AGASIL & Agaricus & silvicola & Agaricaceae & 4 & 50 \\
\hline LACUVI & Lactarius & uvidus & Russulaceae & 4 & 0 \\
\hline AMAFUL & Amanita & fulva & Amanitaceae & 3 & 100 \\
\hline CANCIB & Cantharellus & cibarus & Cantharellaceae & 3 & 100 \\
\hline CHECAN & Cheimonophyllum & candidissimus & Tricholomataceae & 3 & 100 \\
\hline CHLMOL & Chlorophyllum & molybdites & Lepiotaceae & 3 & 100 \\
\hline CRULAE & Crucibulum & laeve & Nidulariaceae & 3 & 100 \\
\hline CYASTR & Cyathus & striatus & Nidulariaceae & 3 & 100 \\
\hline IRPLAC & Irpex & lacteus & Polyporaceae & 3 & 100 \\
\hline LECINS & Leccinum & insigne & Boletaceae & 3 & 100 \\
\hline LENPON & Lentinus & ponderosus & Tricholomataceae & 3 & 100 \\
\hline PHYRHO & Phylloporus & rhodoxanthus & Paxillaceae & 3 & 100 \\
\hline PYCALB & Pycnoporellus & alboluteus & Polyporaceae & 3 & 100 \\
\hline SPAFLA & Spathularia & flavida & Geoglossaceae & 3 & 100 \\
\hline CHRVIN & Chroogomphus & vinicolor & Gomphidiaceae & 3 & 67 \\
\hline GEASAC & Geastrum & saccatum & Geastraceae & 3 & 67 \\
\hline HYPCHR & Hypomyces & chrysospermum & Hypocreaceae & 3 & 67 \\
\hline LEPCRI & Lepiota & cristata & Lepiotaceae & 3 & 67 \\
\hline STESPL & Stemonitis & splendens & Stemonitaceae & 3 & 67 \\
\hline XERAME & Xerula & americana & Tricholomataceae & 3 & 67 \\
\hline ASTHYG & Astraeus & hygrometricus & Astraeaceae & 3 & 33 \\
\hline AMABIS & Amanita & bisporigera & Amanitaceae & 3 & 0 \\
\hline PORCOR & Poria & corticola & Polyporaceae & 3 & 0 \\
\hline CHLAER & Chlorociboria & aeruginascens & Dermatiaceae & 2 & 100 \\
\hline CLIDIL & Clitocybe & dilatata & Tricholomataceae & 2 & 100 \\
\hline CORGAL & Coriolopsis & gallica & Polyporaceae & 2 & 100 \\
\hline DAECON & Daedaleopsis & confragosa & Polyporaceae & 2 & 100 \\
\hline FOMCAN & Fomitopsis & canjanderi & Polyporaceae & 2 & 100 \\
\hline INOSOR & Inocybe & sororia & Cortinariaceae & 2 & 100 \\
\hline
\end{tabular}


Ordered list of fungi,

2 or more occurrences

\begin{tabular}{|c|c|c|c|c|c|}
\hline Abbreviation & Genus & Species & Family & Number of & Percent \\
\hline & & & & samples & reliable \\
\hline LACBAR & Lactarius & barrowsii & Russulaceae & 2 & 100 \\
\hline LENBET & Lenzites & betulina & Polyporaceae & 2 & 100 \\
\hline LYCFLA & Lycogala & flavofuscum & Reticulariaceae & 2 & 100 \\
\hline LYCAME & Lycoperdon & americanum & Lycoperdaceae & 2 & 100 \\
\hline PANFOE & Panaeolus & foenisecii & Coprinaceae & 2 & 100 \\
\hline PENGIG & Peniophora & gigantea & Corticiaceae & 2 & 100 \\
\hline PLULUT & Pluteus & lutescens & Pluteaceae & 2 & 100 \\
\hline SUISIB & Suillus & sibiricus & Boletaceae & 2 & 100 \\
\hline TRIPLA & Tricholomopsis & platyphylla & Tricholomataceae & 2 & 100 \\
\hline ARMALB & Armillaria & albolanaripes & Tricholomataceae & 2 & 50 \\
\hline CALGIG & Calvatia & gigantea & Lycoperdaceae & 2 & 50 \\
\hline CLACOR & Clavulinopsis & corniculata & Clavariaceae & 2 & 50 \\
\hline CONPUT & Coniophora & puteana & Coniophoraceae & 2 & 50 \\
\hline CORCAR & Coriolellus & carbonarius & Polyporaceae & 2 & 50 \\
\hline GOMORE & Gomphidius & oregonensis & Gomphidiaceae & 2 & 50 \\
\hline GYMSAP & Gymnopolis & sapineus & Cortinariaceae & 2 & 50 \\
\hline HUMHEM & Humaria & hemispherica & Pyronemataceae & 2 & 50 \\
\hline INOFAS & Inocybe & fastigiata & Cortinariaceae & 2 & 50 \\
\hline LACBIC & Laccaria & bicolor & Tricholomataceae & 2 & 50 \\
\hline LACTOR & Lactarius & torminosus & Russulaceae & 2 & 50 \\
\hline LYCECH & Lycoperdon & echinatum & Lycoperdaceae & 2 & 50 \\
\hline NIDCAN & Nidula & candida & Nidulariaceae & 2 & 50 \\
\hline PENRUF & Peniophora & rufa & Corticiaceae & 2 & 50 \\
\hline POLELE & Polyporus & elegans & Polyporaceae & 2 & 50 \\
\hline THETER & Thelephora & terrestris & Thelephoraceae & 2 & 50 \\
\hline CLIGIG & Clitocybe & gigantea & Tricholomataceae & 2 & 0 \\
\hline COLLEN & Collybia & lentinoides & Tricholomataceae & 2 & 0 \\
\hline CYSAMI & Cystoderma & amianthinum & Tricholomataceae & 2 & 0 \\
\hline HOHPET & Hohenbuehelia & petaloides & Tricholomataceae & 2 & 0 \\
\hline HYGMAR & Hygrophorus & marginatus & Hygrophoraceae & 2 & 0 \\
\hline LENOMP & Lentinellus & omphalodes & Tricholomataceae & 2 & 0 \\
\hline \multirow[t]{5}{*}{ STEHIR } & Stereum & hirsutum & Stereaceae & 2 & 0 \\
\hline & & & & & \\
\hline & & & Total of all species $=$ & 748 & \\
\hline & & & & & \\
\hline & & & Total $(n>3)=$ & 609 & \\
\hline
\end{tabular}


Appendix C

Fungi Distributions by Habitat 
Fungi Abundances,

by Habitat

\begin{tabular}{|c|c|c|c|c|c|c|c|c|c|c|c|c|}
\hline & & & & \multicolumn{3}{|c|}{ Constancy } & & & \multicolumn{3}{|c|}{ Percent constancy } & \\
\hline ABBREVIATION & GENUS & SPECIES & P-J & CBPP & $\mathrm{PP}$ & CBMC & $\mathrm{MC}$ & P-J & CBPP & $\mathrm{PP}$ & CBMC & $\overline{\mathrm{MC}}$ \\
\hline BJEADU & Bjerkandera & adusta & & & & & 7 & & & & & 50.0 \\
\hline LACLAC & Laccaria & laccata & & & & & 4 & & & & & 28.6 \\
\hline COPATR & Coprinus & atramentarius & & & & & 3 & & & & & 21.4 \\
\hline LECAUR & Leccinum & aurantiacum & & & & & 3 & & & & & 21.4 \\
\hline LYCPYR & Lycoperdon & pyriforme & & 1 & & & 2 & & 10.0 & & & 14.3 \\
\hline CREMOL & Crepidotus & mollis & & & & 2 & 12 & & & & 333 & 857 \\
\hline GOMGLU & Gomphidius & glutinosus & & & & 3 & 9 & & & & 50.0 & 64.3 \\
\hline FLAVEL & Flammulina & velutipes & & 1 & & 1 & 9 & & 10.0 & & 16.7 & 64.3 \\
\hline FOMPIN & Fomitopsis & pinicola & & & & 5 & 8 & & & & 83.3 & 57.1 \\
\hline LEUAMA & Leucopaxillus & amarus & & 1 & & 2 & 6 & & 10.0 & & 33.3 & 42.9 \\
\hline PHOSQU & Pholiota & squarrosa & & & & 1 & 5 & & & & 16.7 & 35.7 \\
\hline CYPCHR & Cyptotrama & chrysopeplum & & & & 5 & 4 & & & & 83.3 & 28.6 \\
\hline CLAPYX & Clavicorona & pyxidata & & & & 2 & 4 & & & & 33.3 & 28.6 \\
\hline HEBCRU & Hebeloma & crustiliniforme & & & & 2 & 4 & & & & 33.3 & 28.6 \\
\hline GLOSEP & Gloepphyllum & sepiarium & & & & 1 & 4 & & & & 16.7 & 28.6 \\
\hline RUSROS & Russula & rosacea & & & & 2 & 3 & & & & 33.3 & 21.4 \\
\hline BISCIT & Bisporella & citrina & & & & 1 & 3 & & & & 16.7 & 21.4 \\
\hline GYRINF & Gyromitra & infula & & & & 1 & 2 & & & & 16.7 & 14.3 \\
\hline & & & & & & & & & & & & \\
\hline SUILAK & Suillus & lakei & & & 1 & 4 & 8 & & & 14.3 & 66.7 & 57.1 \\
\hline XERCAM & Xeromphalina & campanella & & & 2 & 6 & 7 & & & 28.6 & 100.0 & 50.0 \\
\hline GOMFLO & Gomphus & floccosus & & & 1 & 2 & 6 & & & 14.3 & 33.3 & 42.9 \\
\hline COPMIC & Coprinus & micaceus & & & 1 & 1 & 6 & & & 14.3 & 16.7 & 42.9 \\
\hline GANAPP & Ganoderma & applanatum & & & 1 & 1 & 5 & & & 14.3 & 16.7 & 35.7 \\
\hline DACPAL & Dacrymyces & palmatus & & & 1 & 3 & 3 & & & 14.3 & 50.0 & 21.4 \\
\hline RUSEME & Russula & emetica & & & 3 & 2 & 3 & & & 42.9 & 33.3 & 21.4 \\
\hline CORCAL & Cortinarius & calochrous & & & 1 & 2 & 3 & & & 14.3 & 33.3 & 21.4 \\
\hline LACRUB & Lactarius & rubrilacteus & & & 3 & 1 & 2 & & & 42.9 & 16.7 & 14.3 \\
\hline HYGPUD & Hygrophorus & pudorinus & & & 2 & 1 & 2 & & & 28.6 & 16.7 & 14.3 \\
\hline AURAUR & Auricularia & auricula & & & $t$ & 3 & 1 & & & 14.3 & 50.0 & 7.1 \\
\hline & & & & & & & & & & & & \\
\hline & & & & & & & & & & & & \\
\hline
\end{tabular}


Fungi Abundances,

by Habitat

\begin{tabular}{|c|c|c|c|c|c|c|c|c|c|c|c|c|}
\hline & & & & \multicolumn{3}{|c|}{ Constancy } & & & \multicolumn{3}{|c|}{ Percent constancy } & \\
\hline ABBREVIATION & GENUS & SPECIES & P-J & CBPP & $\mathrm{PP}$ & CBMC & MC & P-J & CBPP & $\overline{P P}$ & CBMC & $\mathrm{MC}$ \\
\hline & & & & & & & & & & & & \\
\hline PLUCER & Pluteus & cervinus & & 2 & 2 & 3 & 7 & & 20.0 & 28.6 & 50.0 & 50.0 \\
\hline BOLBAR & Boletus & barrowsii & & 1 & 2 & 2 & 6 & & 10.0 & 28.6 & 33.3 & 42.9 \\
\hline SUIGRA & Suillus & granulatus & & 6 & 4 & 4 & 3 & & 60.0 & 57.1 & 66.7 & 21.4 \\
\hline AMAMUS & Amanita & muscaria v. mus. & & 1 & 2 & 2 & 2 & & 10.0 & 28.6 & 33.3 & 14.3 \\
\hline HYPLAC & Hypomyces & lactifluorum & & 1 & 1 & 2 & 2 & & 10.0 & 14.3 & 33.3 & 14.3 \\
\hline AMAVAG & Amanita & vaginata & & 1 & 3 & 1 & 2 & & 10.0 & 42.9 & 16.7 & 14.3 \\
\hline AMAPAN & Amanita & pantherina & & 2 & 1 & 1 & 2 & & 20.0 & 14.3 & 16.7 & 14.3 \\
\hline PHASCH & Phaeolus & schweinitzii & & 1 & 1 & 1 & 2 & & 10.0 & 14.3 & 16.7 & 14.3 \\
\hline & & & & & & & & & & & & \\
\hline PLEOST & Pleurotus & ostreatus & & 1 & & 3 & 4 & & 10.0 & & 50.0 & 28.6 \\
\hline TRIABI & Trichaptum & abietinus & & 1 & & 3 & 2 & & 10.0 & & 50.0 & 14.3 \\
\hline BOLCHR & Boletus & chrysenteron & & 2 & & 2 & 2 & & 20.0 & & 33.3 & 14.3 \\
\hline POLVAR & Polyporus & varius & & 1 & & 1 & 2 & & 10.0 & & 16.7 & 14.3 \\
\hline AGASIL & Agaricus & silvicola & & 1 & & 1 & 2 & & 10.0 & & 16.7 & 14.3 \\
\hline PYCCIN & Pycnoporus & cinnabarinus & & 2 & & 3 & 1 & & 20.0 & & 50.0 & 7.1 \\
\hline & & & & & & & & & & & & \\
\hline GOMBON & Gomphus & bonari & & & 1 & & 3 & & & 14.3 & & 21.4 \\
\hline CLIGIB & Clitocybe & gibba & & & 1 & & 3 & & & 14.3 & & 21.4 \\
\hline COLPER & Coltricia & perennis & & & 1 & & 3 & & & 14.3 & & 21.4 \\
\hline COPCOM & Coprinus & comatus & & & 1 & & 3 & & & 14.3 & & 21.4 \\
\hline LACUVI & Lactarius & uvidus & & & 1 & & 3 & & & 14.3 & & 21.4 \\
\hline HYGSPE & Hygrophorus & speciosus & & & 3 & & 2 & & & 42.9 & & 14.3 \\
\hline BOLEDU & Boletus & edulis & & & 2 & & 2 & & & 28.6 & & 14.3 \\
\hline PEZREP & Peziza & repanda & & & 1 & & 2 & & & 14.3 & & 14.3 \\
\hline ARMMEL & Armillaria & mellea & & 2 & 1 & & 7 & & 20.0 & 14.3 & & 50.0 \\
\hline LACDEL & Lactarius & deliciosus & & 4 & 3 & & 4 & & 40.0 & 42.9 & & 28.6 \\
\hline PHYNID & Phyllotopsis & nidulans & & 1 & 1 & & 4 & & 10.0 & 14.3 & & 28.6 \\
\hline HYGCON & Hygrophorus & conicus & & 3 & 3 & & 3 & & 30.0 & 42.9 & & 21.4 \\
\hline HEBSIN & Hebeloma & sinapizans & & 2 & 1 & & 3 & & 20.0 & 14.3 & & 21.4 \\
\hline CLATRU & Clavariadelphus & truncatus & & 2 & 1 & & 3 & & 20.0 & 14.3 & & 21.4 \\
\hline HELCRI & Helvella & crispa & & 2 & 1 & & 1 & & 20.0 & 14.3 & & 7.1 \\
\hline
\end{tabular}


Fungi Abundances,

by Habitat

\begin{tabular}{|c|c|c|c|c|c|c|c|c|c|c|c|c|}
\hline & & & & \multicolumn{3}{|c|}{ Constancy } & & & \multicolumn{3}{|c|}{ Percent constancy } & \\
\hline ABBREVIATION & GENUS & SPECIES & P-J & CBPP & $\mathrm{PP}$ & CBMC & $\mathrm{MC}$ & P.J & CBPP & PP & CBMC & $\mathrm{MC}$ \\
\hline LYCPER & Lycoperdon & perlatum & 1 & 1 & 1 & 3 & 4 & 16.7 & 10.0 & 14.3 & 50.0 & 28.6 \\
\hline RUSBRE & Russula & brevipes & 2 & 2 & 3 & 1 & 3 & 33.3 & 20.0 & 42.9 & 16.7 & 21.4 \\
\hline LYCEPI & Lycogala & epidendrum & 1 & 1 & 2 & & 6 & 16.7 & 10.0 & 28.6 & & 42.9 \\
\hline RUSMAC & Russula & maculata & 1 & 1 & 2 & & 3 & 16.7 & 10.0 & 28.6 & & 21.4 \\
\hline FULSEP & Fuligo & septica & 1 & 1 & 1 & & 2 & 16.7 & 10.0 & 14.3 & & 14.3 \\
\hline HYGCHR & Hygrophorus & chrysodon & 1 & 2 & 3 & & 1 & 16.7 & 20.0 & 42.9 & & 7.1 \\
\hline HYGAUR & Hygrophoropsis & aurantiaca & & & 1 & 3 & & & & 143 & 500 & \\
\hline AMACAE & Amanita & caesarea & & & 2 & 1 & & & & 28.6 & 16.7 & \\
\hline PHODES & Pholiota & destruens & & 4 & & 2. & & & 40.0 & & 33.3 & \\
\hline POLARC & Polyporus & arcularius & 1 & 5 & 4 & 1 & & 16.7 & 50.0 & 57.1 & 16.7 & \\
\hline MARORE & Marasmius & oreades & & & 2 & & & & & 28.6 & & \\
\hline AGACAM & Agaricus & campestris & & 2 & 1 & & & & 20.0 & 14.3 & & \\
\hline AMACON & Amanita & constricta & 3 & 1 & 1 & & & 50.0 & 10.0 & 14.3 & & \\
\hline
\end{tabular}




\section{Appendix D}

Histograms of Fungi Distributions, by Fidelity Grouping 


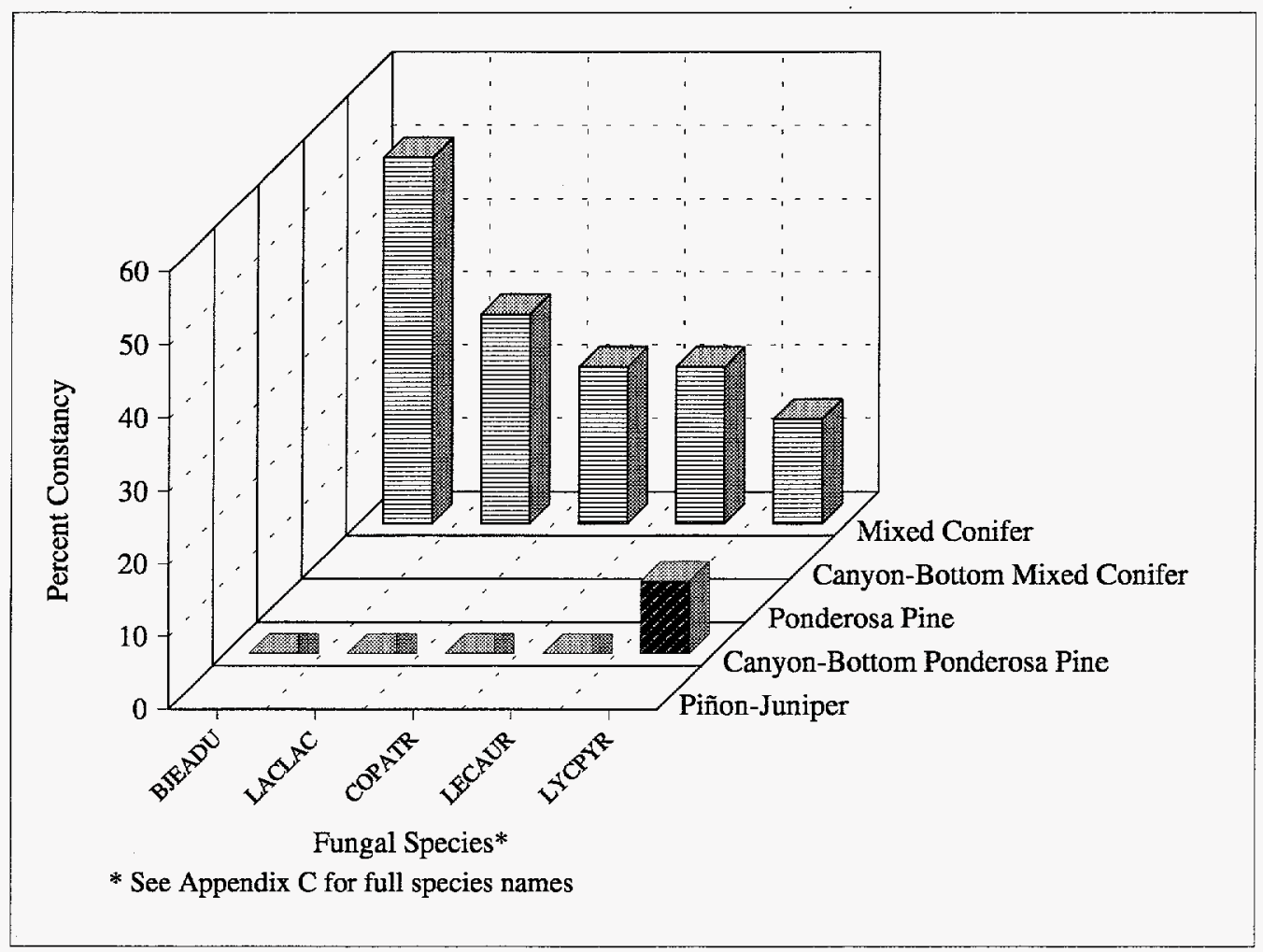

Figure 1. Fungal species found in the mixed conifer habitat.

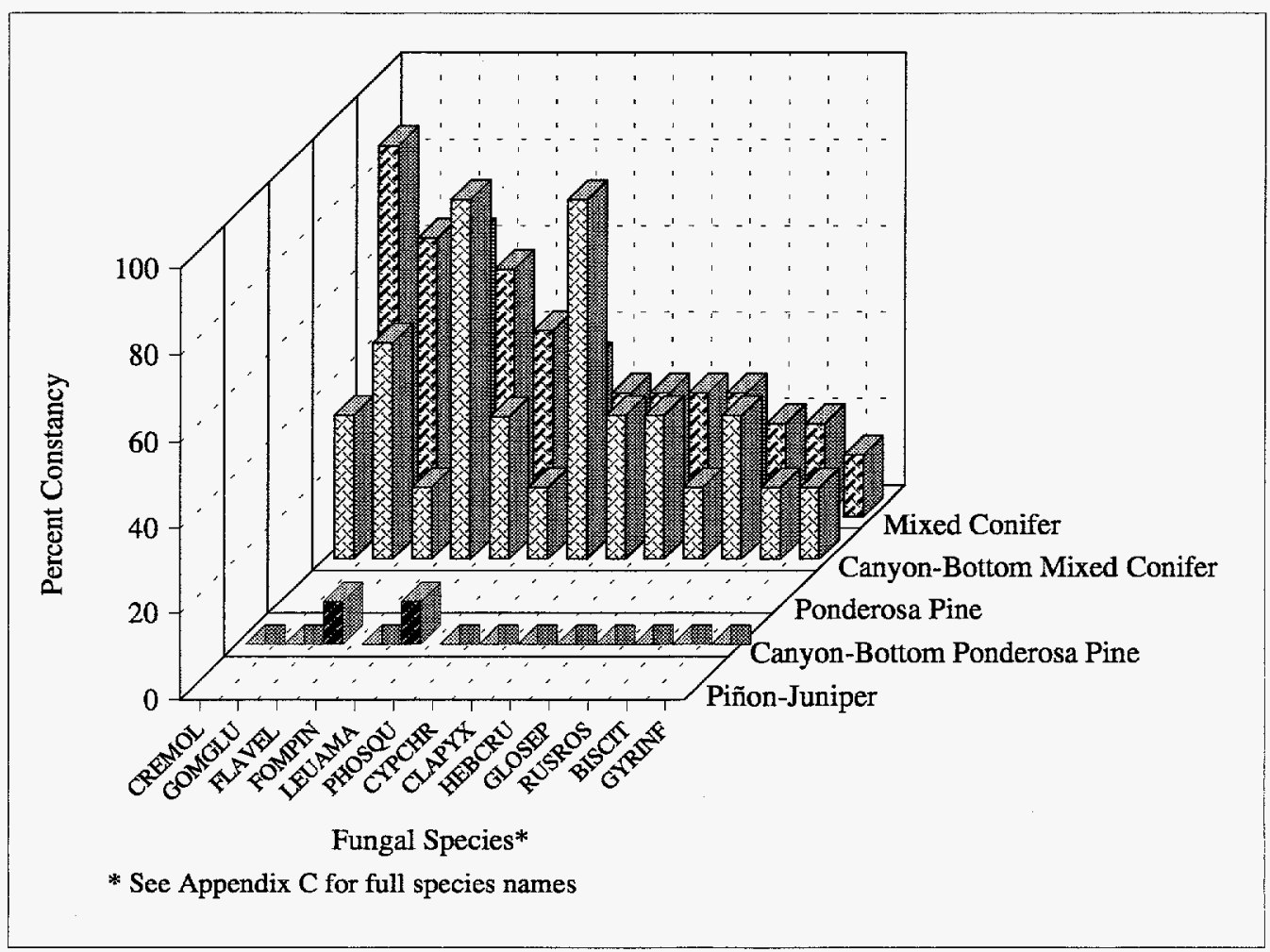

Figure 2. Fungal species found in canyon-bottom mixed conifer and mixed conifer habitat. 


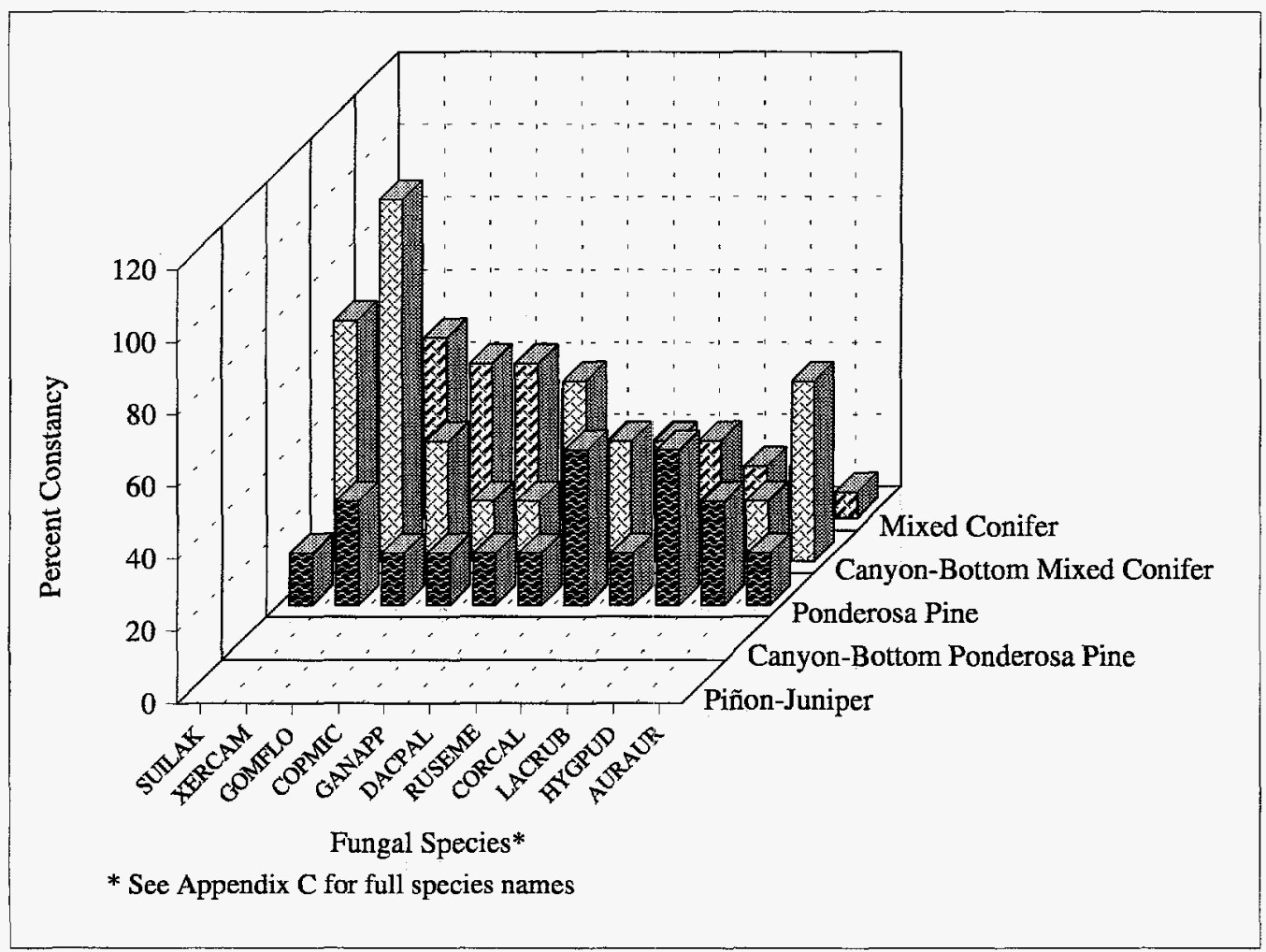

Wigure 3 . Fungal species found in ponderosa pine, canyon-botom mixed conifer, and mixed conifer.

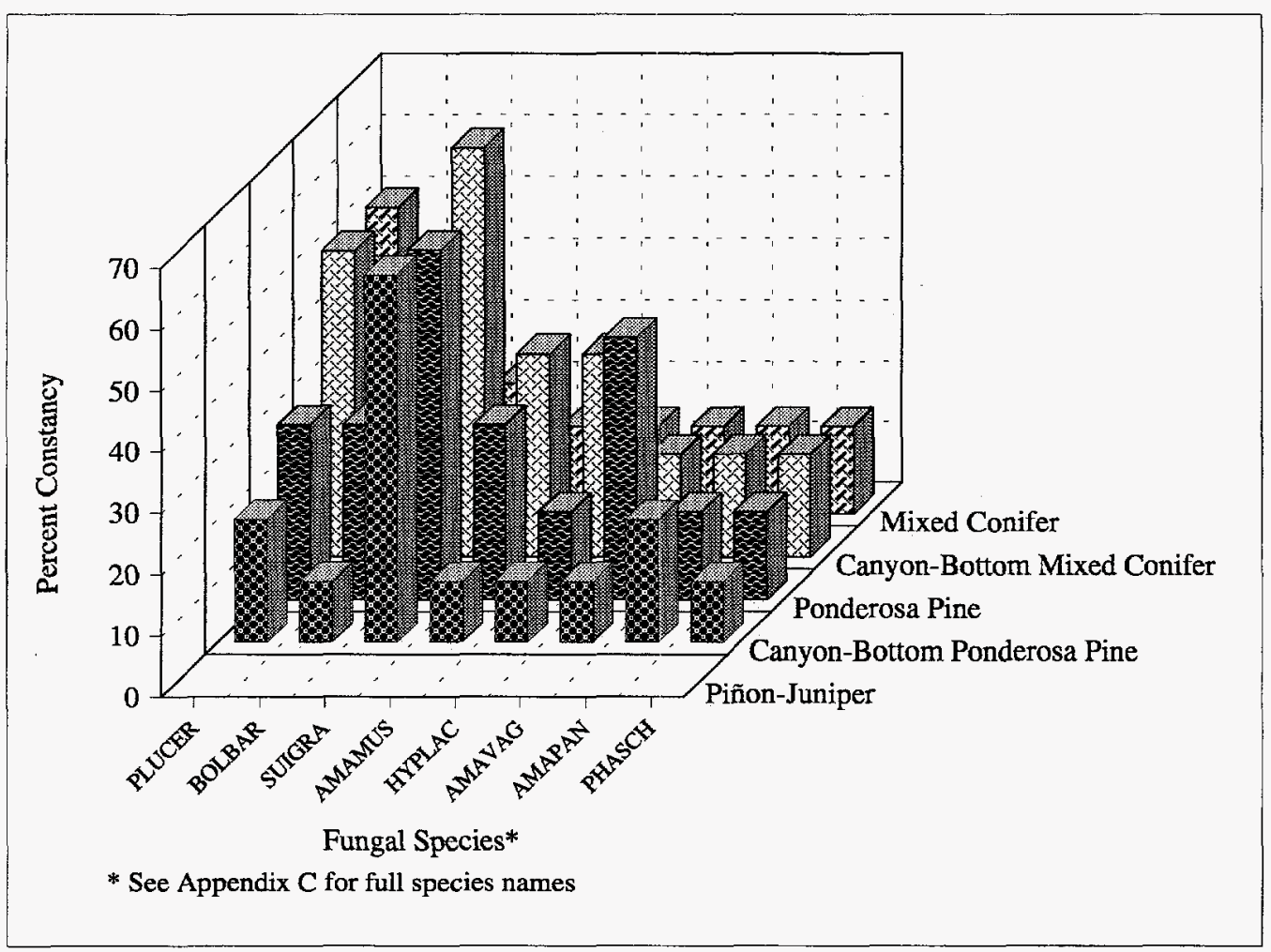

Figure 4. Fungal species foung in all hatitats except piñon-juniper. 


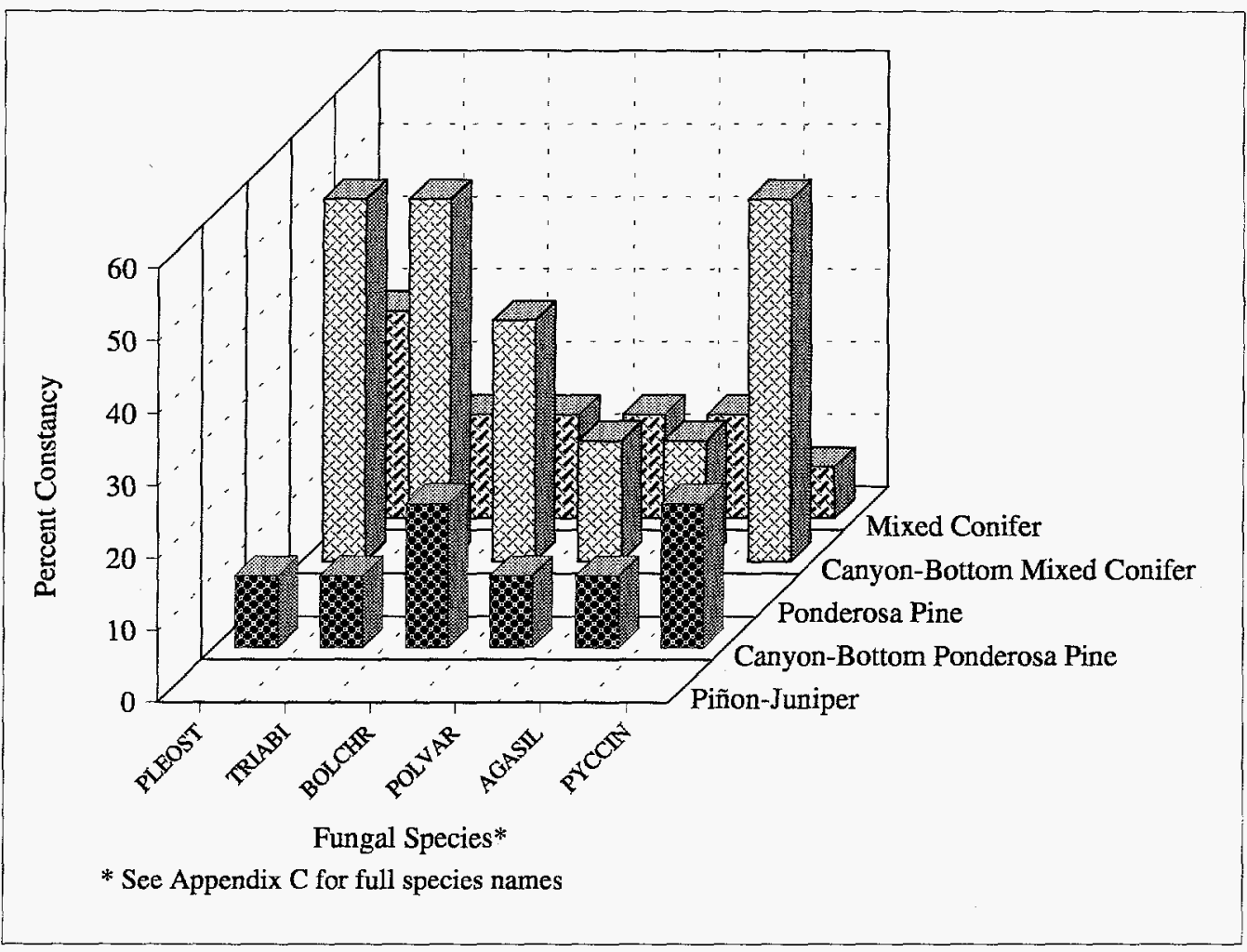

Figure 5. Fungal species found in canyon-bottom ponderosa pine, canyon-bottom mixed conifer, and mixed conifer habitats.

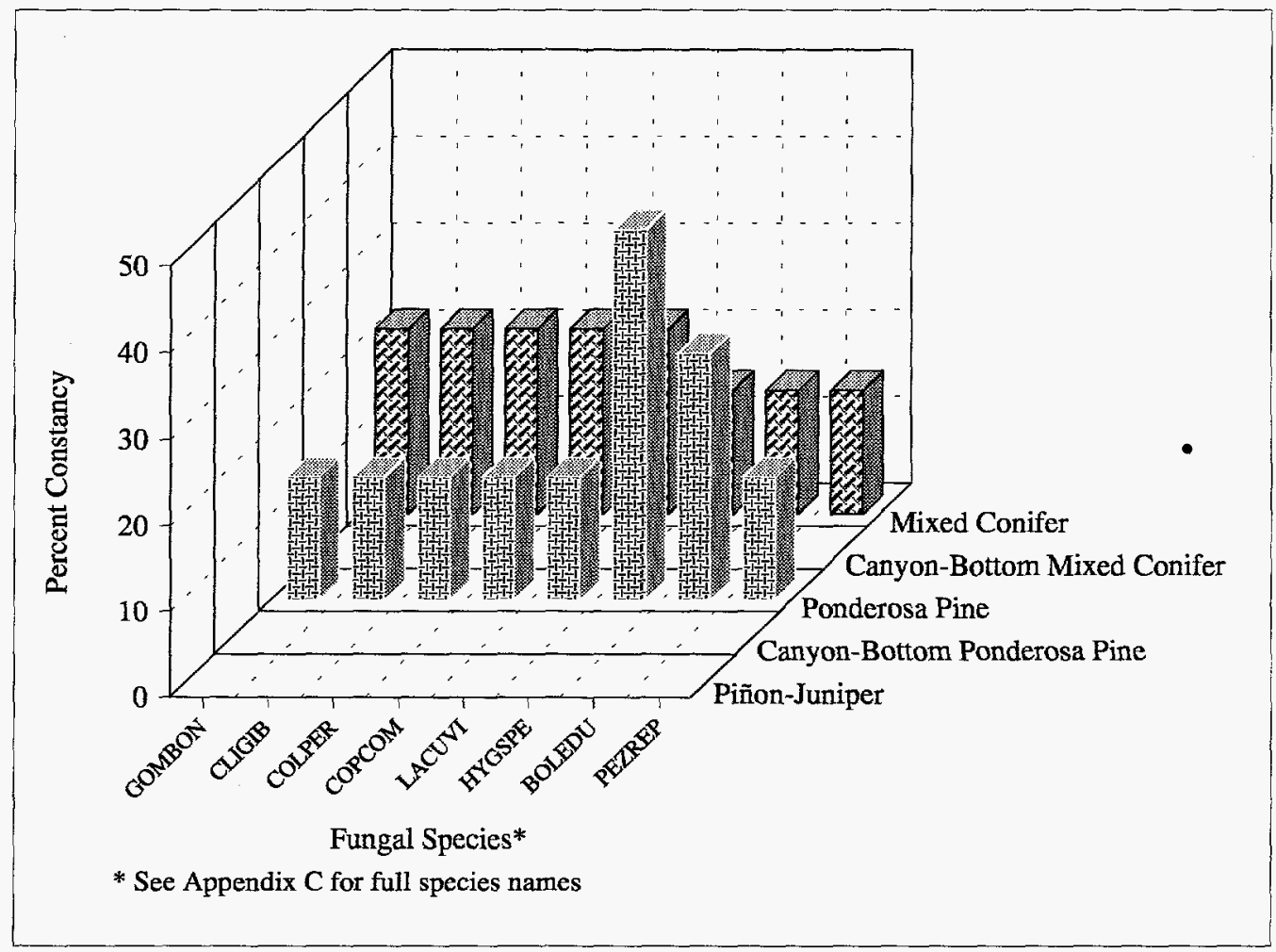

Figure 6. Fungal species found in the ponderosa pine and mixed conifer habitats. 


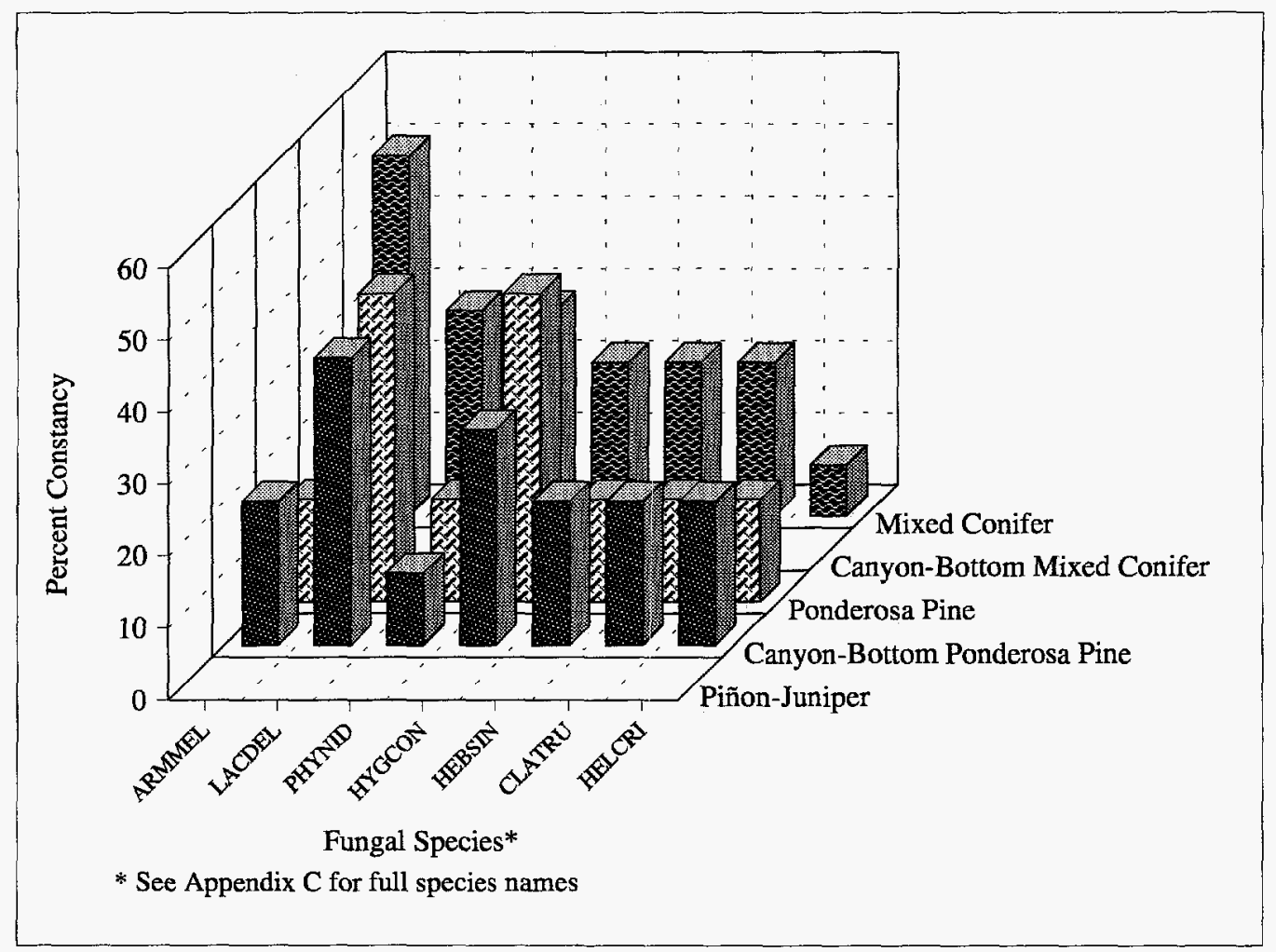

Figure 7. Fungal species found in the canyon-bottom ponderosa pine, ponderosa pine, and mixed conifer.

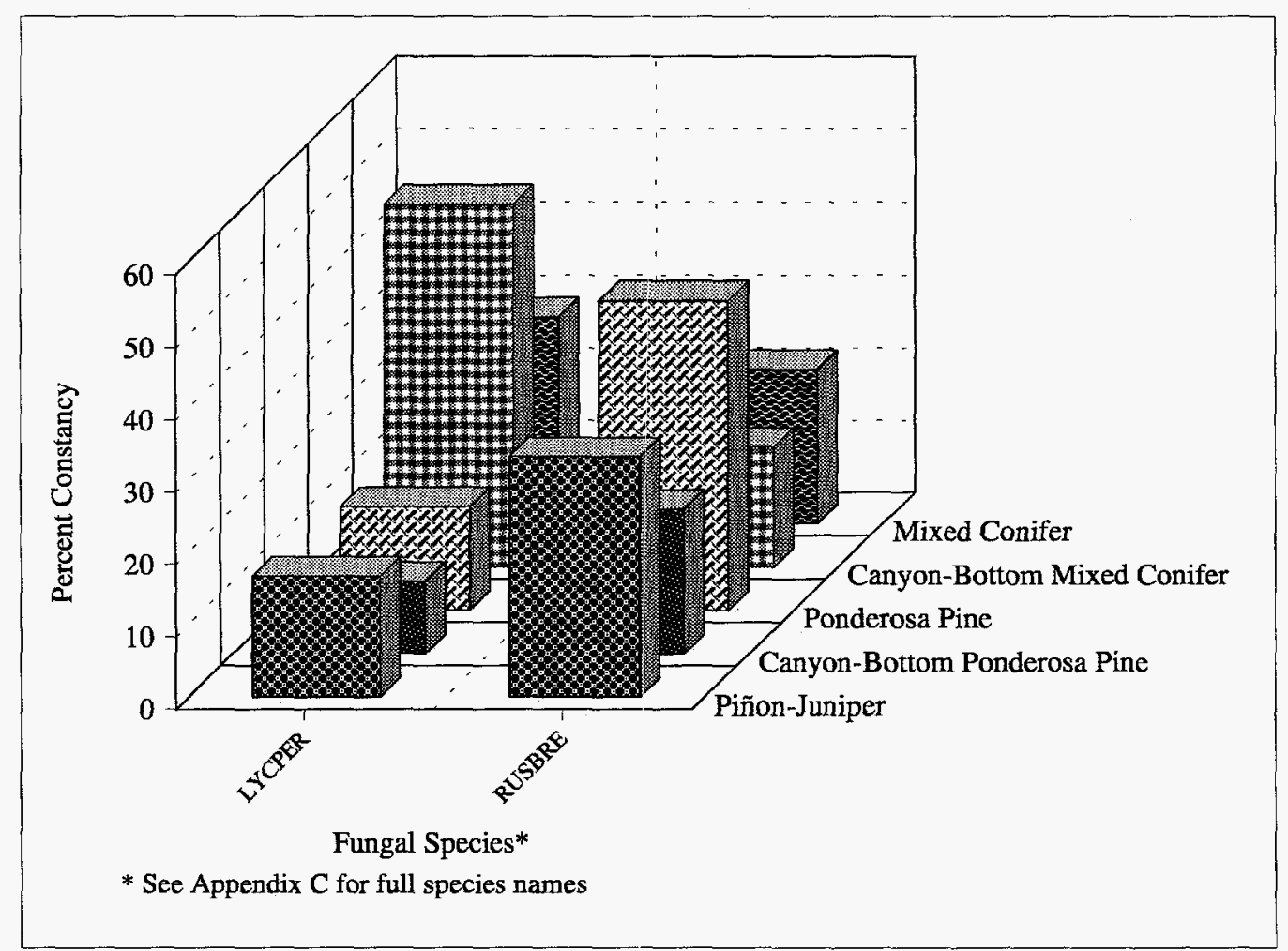

Figere 8. Fungal species found in all habitats. 


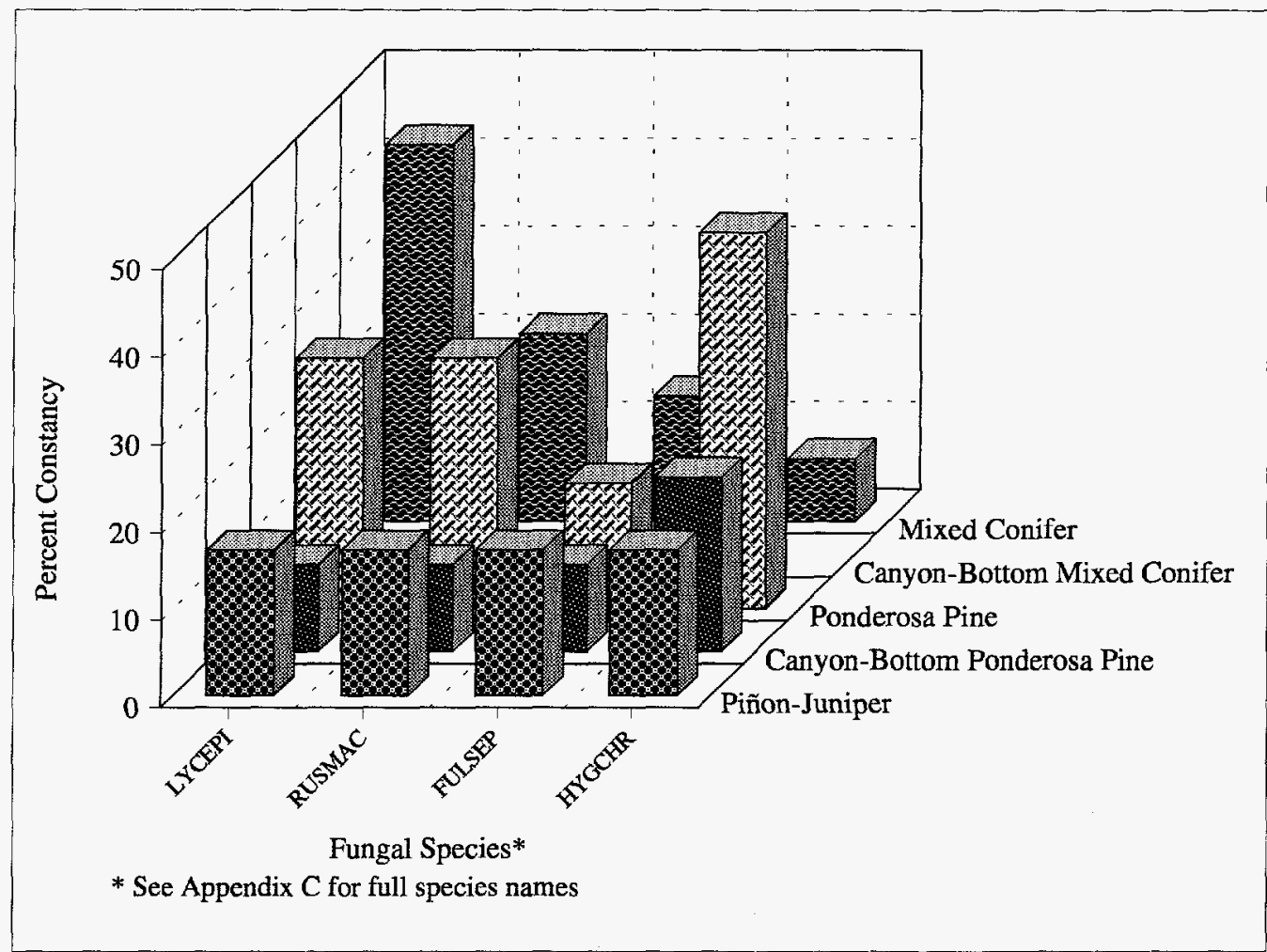

Tigure 9. Fmgal species found in pinon-jumper, canyon-botom ponderosa pine, ponderosa pine, and mixed conifer.

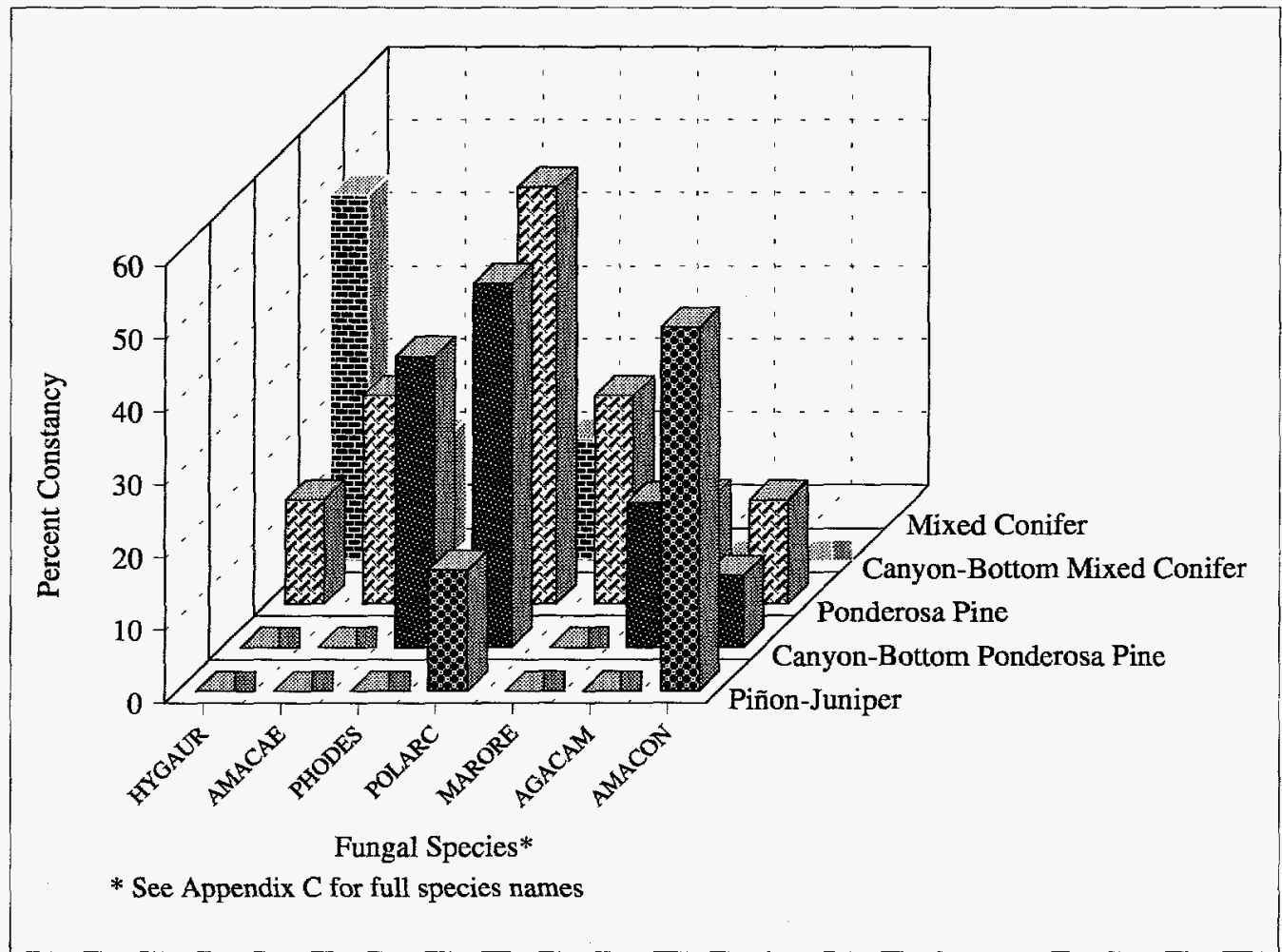

Nigure 10. Fungal species found in pinon-juniper, canyon-botrom ponderosa pine, and canyon-botom mixed conifer habitats. 
